\title{
急性単純性膀胱炎治療およびその後の再発に関する研究
}

一Nalidixic acid による検討一

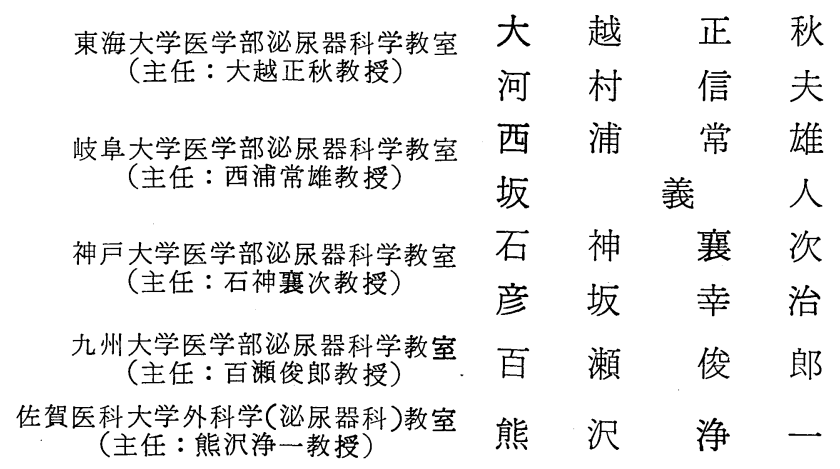

\section{EVALUATION OF RECURRENCE AFTER TREATMENT OF URINARY TRACT INFECTIONS}

Masaaki Ohkoshi and Nobuo Kawamura

Department of Urology, School of Medicine, Tokay University

(Director: Prof. M. Ohkoshi)

Tsuneo Nishiura and Yoshihito Ban

Department of Urology, Gifu University, School of Medicine

(Director: Prof. T. Nishiura)

Joji Ishigami and Koji Hikosaka

Department of Urology, Kobe University, School of Medicine

(Director: Prof. J. Ishigami)

Shunro Momose

Department of Urology, Faculty of Medicine, Kyushu University

(Director: Prof. S. Momose)

Joichi Kumazawa

Department of Surgery (Urology), Saga Medical School

(Director: Prof. J. Kumazawa)

Nalidixic acid (NA) was administered to female patients with acute simple cystitis at a dose of $2 \mathrm{~g}$ daily for 3 days to determine its efficacy. Recurrence rate and factors causing recurrence were also discussed based on the results of a follow-up survey.

Upon completion of a 3-day treatment with NA at a dose of $2 \mathrm{~g}$ daily, efficacy of the drug was assessed according to the Criteria for Drug Evaluation by UTI Study Group. 430 out of 808 patients collected from 103 institutions were subjected to the evaluation. The remaining cases were excluded because of various reasons. $258(60 \%)$ out of the 430 cases showed "Excellent" response to NA and "Good" in 110 patients $(25.6 \%)$. The overall efficacy rate was $85.6 \%$.

Then the follow-up treatment for 7 days was done in 368 patients of "Excellent" or "Good" and reexamined. Inter-group comparison was made, where Group A received NA $1 \mathrm{~g}$ for 7 days and a low dose of 
antiinflammatory agent was given to Group B for a week following the initial treatment. No treatment was done in Group C following the initial treatment. The recurrence was less frequent in Group A, while higher incidence of recurrence was observed in Groups B and C. It was found that the recurrence rate in those patients showing "Good" response to the initial 3-day treatment with NA was higher than that of the "Excellent" Group. It is to note that relatively high incidence of recurrence was observed in those patients with persisting bacteria in urine, even if its bacterial count was less than $10^{4} / \mathrm{ml}$.

要旨：女子の急性単純性膀胱炎にナリジクス酸 (NA) $2 \mathrm{~g}$ を 3 日分投与し, 現時点に扣けるこの薬剤の効力 を検討し，かつ追跡調査により，再発率と再発に至る条件について考察を加えた。 NA $2 \mathrm{~g}$ を 3 日分投与し終 つた時点で, 大越らの UTI 薬効評価基準にもとづいて効果の判定を行つた. 103施設から集められた808例か ら, 種々の理由による除外, 脱落を経て残つた430例の急性単純性膀胱炎で, そのらち NA が著効と判定され た例は258例 $(60.0 \%)$ あり，有効は110例で総合有効率は $85.6 \%$ でつた. 3 日分の NA 投与後, 経過観察 期間を 7 日間おいて再検査したが，その 7 日間に NA $1 \mathrm{~g}$ を継続投与した群，少量の抗炎症剤のみを投与した 群, 何も投与しなかつた群の比較では, NA $1 \mathrm{~g}$ 投与継続群に再発が少なく, その他の群に再発が多かつた. また 3 日目の時点で著効と判定された群より, 有効と判定された群の方が再発が多かつた．中でも尿中細菌が $10^{4}=/ \mathrm{ml}$ 以下の数であつても残存している症例に, 再発の多い傾向がみとめられた.

\author{
緒言 \\ ナリジクス酸 (以下 NA と略記) を女子の急性単純 \\ 性膀胱炎の患者に投与し, 現時点に扣计る有效率と, 一 \\ 旦治癒した後の再発率, 再発例の病態について検討を試 \\ みた. \\ 本研究は, 地域による片寄りをなくすため全国的に研
}

表 1 研究参加機関 (順不同)

\begin{tabular}{|c|c|c|c|c|}
\hline 東＼cjkstart海 & 学 & 三 重 大 学 & 健 保松下病 院 & 市 立 小倉 病 院 \\
\hline 平塚市 民 病 & 院 & 名古屋第一赤十字病院 & 京都第一赤十字病院 & 九州厚生年金病院 \\
\hline 虎 の 門 病 & 院 & 名古屋保健衛生大学 & 健保鞍馬口病院 & 国立福岡中央病院 \\
\hline 京大 & 学 & 神 戸 大 学 & （京 都 大 学） & 八幡製鉄所病院 \\
\hline 三井 記 念 病 & 院 & 社保神戸中央病院 & 大津市民病 院 & 国 立 別 府 病 院 \\
\hline 武蔵野赤十字病 & 院 & 神 鋼 病 院 & （金 沢 大 学) & 県 立宮 崎 病 院 \\
\hline 埼 玉 中 央 病 & 院 & 赤 穂 市 民 病 院 & 藤 & 三信 会 原 病 院 \\
\hline 慈恵医 科大 & 学 & 新 日鉄広畑病院 & 岡 山 大 & 広島赤十字病院 \\
\hline 北 里 大 & 学 & 神戸掖済会病院 & 岡 山市民 病 院 & 王丸クリニック \\
\hline 新＼cjkstart潟大 & 学 & 県 立尼崎病 院 & 岡山済生会病院 & 日高クリニック \\
\hline 新潟県立ガンセンタ & - & 県立加古川病院 & 岡山赤十字病院 & 安藤クリニック \\
\hline 県 立 新 発 田 病 & 院 & 市立西 脇 病 院 & 川崎医 科大学 & 清＼cjkstart原＼cjkstart医 \\
\hline 県 立 吉 田 病 & 院 & 明 石 市 民病 & 津 山 中 央 病 & 久留 米大 \\
\hline 三条総 合 病 & 院 & 神 戸労 災 病 院 & 川＼cjkstart崎＼cjkstart病 & 国 立小倉 病 院 \\
\hline 長岡中央総合病 & 院 & 姫路赤十字病院 & 玉 野市 民 病 院 & 大牟田市立病 院 \\
\hline 小千谷 総 合 病 & 院 & 大阪医 科大学 & （広 島 大 学） & 社保久留米第一病院 \\
\hline 県 立 加 茂 病 & 院 & 北 摄 病 院 & 松山赤十字病院 & 国立久留米病院 \\
\hline 新潟 労 災 & 院 & 済生会中津病院 & 国 立 呉 病 院 & （鹿 児 島 大 学） \\
\hline 新潟市 民病 & 院 & 大津赤十字病院 & 尾 道 総 合 病 & 鹿児島市立病院 \\
\hline 水 戸 協 同 & 院 & 奈良医科大学 & 徳 島 大 学 & 国立鹿児島病 院 \\
\hline 市 立 酒 田 & 院 & 県 立 奈 良 病 院 & 徳島県立中央病 院 & 国立指宿温泉中央病院 \\
\hline 平 鹿 総 合 病 & 院 & 大和高田市立病院 & 阿南医師会中央病院 & 片平皮膚泌尿器科 \\
\hline 岐＼cjkstart阜大 & 学 & 済生会中和病 院 & 赤 沢 医 院 & 富山皮虐泌尿器科 \\
\hline 卜 $\exists$ 夕病 & 院 & 国立奈良病 院 & 浜田皮虐泌尿器科 & とまり 医 院 \\
\hline 大垣市 民病 & 院 & 大 阪 回 生 病 & 九 州大 学 & 川内皮膚泌尿器科 \\
\hline 岐 阜 市 民 病 & 院 & 大阪市立城北病院 & 福 岡 大 & 福 崎 医 院 \\
\hline 高山赤十字病 & 院 & 京都府立医科大学 & 宮 崎 医 科 大 & \\
\hline
\end{tabular}


究参加機関をつのり, 表 1 亿示す103機関が協力して行 つたものである. 但し, 成績の解析は東海大学が主とな つて, 表記の 4 大学がこれに協力して和こなわれた.

\section{対象患者と方法}

UTI 研究会の作成した薬効判定基準を基として, 対 象患者を選び, 薬効の判定を行つた.すなわち急性単純 性膀胼炎の 患者の中で, 16 70歳の 女性で 初診時尿中 白血球数 1 視野 10 コ以上，尿中細菌数 $10^{4} \sqsupset / \mathrm{ml}$ 以上であ り, 自覚症状として排尿痛を有し, 且つ発症よりの経過 が14日以内の者を対象にした。

$\mathrm{NA}$ の投与量は，1 日量 $2,000 \mathrm{mg}$ を 4 回に分服するこ ととし，原則として他剤の併用を行わないことにした。

投与日数は 3 日間とし, 服用終了後に諸検査を施行 し, UTI 薬効判定基準に従つて, 著効, 有効, 無効の 3段階に判定した.

ここで，3日間投与による有効率を算出し無効の症例 は除外して，必要あれば他剤による治療に変更し，著効 及び有効の例については, さらに 7 日後, 即ち治療開始 日から10日目に尿検查等を行い，再発の有無を検討す ることにした。NA投与の 3 日間以後, 即ち 4 日目から 再び検查を行う10日目迄の間は,

(1) 無投薬群

(2) メピリゾール 1 日 $100 \mathrm{mg}$ 又は，これに準ずる他 の抗炎症剤の少量を投与する群

(3) NA 1,000mgを1日1回のみ投与する群の 3 群 にわけ, 参加各機関の自由意志で, ぞれかの方法を選ば せた. 同一機関内で異なつた 2 群の, または 3 群の投与 法を行つたところもあるが, 症状の軽重により, どの群 の投与法をとるかを決めることのないように配虑した。

再発の判定については, 大越正秋, 河村信夫, 熊沢浄 一, 坂 義人, 彦坂幸治の 5 名より成る小委員会で検討 した．その結果，NA をはじめ，3 日分投与した時点で 著効と判定された例のみを対象にして再発の有無を判定 することとし, 再感染, 再燃の区別なく, 共に再発の語 で便宜的に 扱うこととした. 再発という判定は，薬効 が著効を示したが，10日後の検査時にUTI 薬効評価基 準 ${ }^{12}$ ) 3) で対象とする膀胱炎の条件を満たす感染の起こつ たものとすることとした（表 2).

このような基準の下で，各機関から集められた808例 の症例を検討し, 投与規定, 検査規定, 対象条件等の違 反，その他表 3 の如き理由による除外，脱落の202例を 除いた606例のうち，判定日のズレのある176例をさらに 除いた.
表 2 再発判定基準

\begin{tabular}{|c|c|}
\hline 分 & 基 \\
\hline 再発あり & 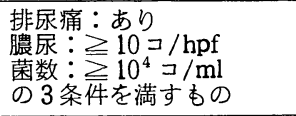 \\
\hline 再発なし & $\begin{array}{l}\text { 排尿痛：なし } \\
\text { 膿尿：0〜4 / hpf } \\
\text { 菌数：0 } \\
\text { の3条件を満すむの }\end{array}$ \\
\hline 再 発 疑 & $\begin{array}{l}\text { 再発「あり」又は「なし」 } \\
\text { の条件の中間にあるあの }\end{array}$ \\
\hline
\end{tabular}

表 3 除外・脱落例の内訳

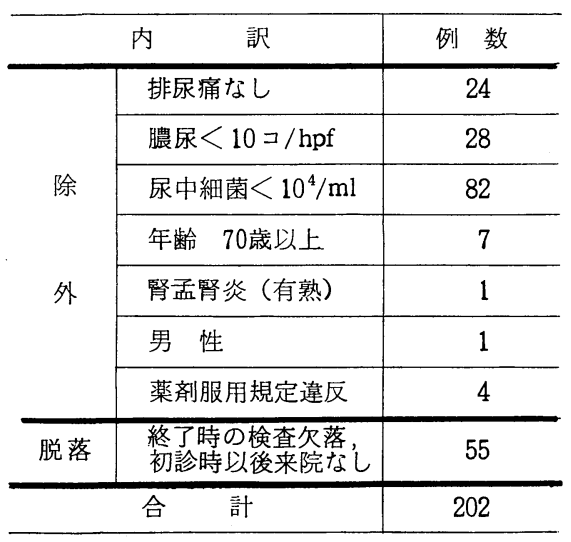

残りの430例の中で， 3 日分の NA 投与の効果が「著 効」と判定されたものは，258例めり，これについて再 発の有無を判定することにしたが，らち91例の除外, 脱 落例があり，実際の検討対象となつたのは167例である (表 4 ).

投与規定違反として処理される176例のらちわけは様 々で, NA2g 4 日以上投与のものが多い。それらの内 3 日分投与後の判定が 可能のものは，別体でNA 3 日間 投与後の効果の判定にくみ入れた。 またこの群のなか には NA 2gを7日間投与したものが101例あり，そこ で著効といら成績を得たもの74例，さらにその後 7 日間 NA $1 \mathrm{~g}$ を投与した例は 26 , 無投与又は少量消炎剤投与 例は28あるので，これらは別にまとめて，7 日目判定14 日目再発判定群として比較した. 但しこれらの症例は投 与 3 日目の判定が行われていないものもあるため, その 時点での効果がわからず, 再発の結果も, 3 日分投与群 と単純に比較できるデータではない。また NA $2 \mathrm{~g} 7$ 日 間投与の症例は, 完全治癒後の再発の検討を企画した一 部の地区の症例が含まれているが，その他の症例なかに はこの方法を選んだ理由に, 疾患の重症度, 再発度など 
表 4 再発判定の為の解析対象

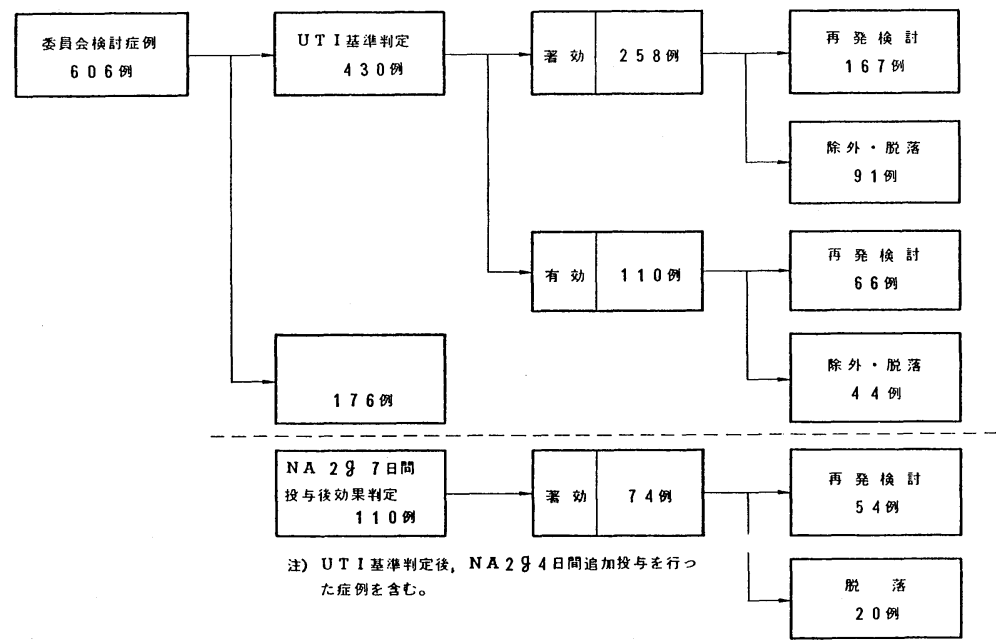

表 5 方法
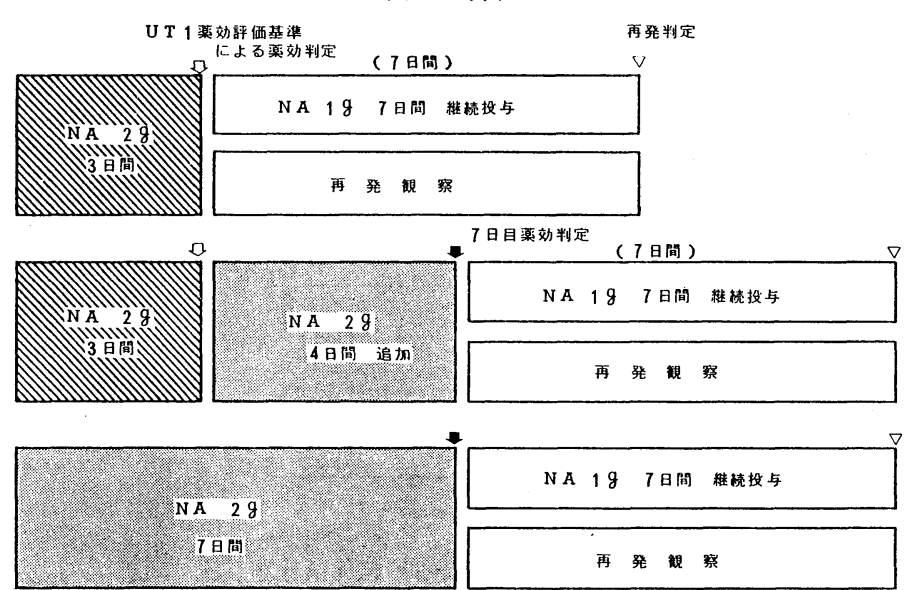

が加味されている場合もあると思われるので，此較して 論ずるには多少の危険性が考えられる。

これらの投与方法の相異と，その各症例数を表 5 にま とめた。

本研究の際の検出方法は次の通りである. 原則として 菌種, 菌数の判定は各機関の検出の結果に従つたが，そ れらの検出が不能な機関のものは，尿にウリカルトをひ たして，そのまま送付してもらい，東京総合臨床検査セ ンターに依頼して, 菌種, 菌数を判定してもらつた. 従 つて各機関では臨床的に意義のある菌のみをひろつて, その菌種, 菌数を判定して扣り, 検査センターでは出た 菌すべてについて菌種菌数を判定しているといら傾向が
ある.そのためか，39例の複数菌感染例の内，10例は検 查センターで, 13例は各機関で複数菌感染と判定された ものであり, 残りの16例は各機関でも検査センターでも 複数菌感染と判定された. 即ち自分の病院で判定せず, 検查センターに判定を依頼した症例については複数菌感 染と判定されている率が高く，その為かなりのバイアス が結果にも入つて来ているという事実がある.

\section{結 果}

1）背景因子について

606例の解析を表 6 に示す．年㱓分布はやや高秢者に 傾いているが，UTI 研究会の行つた基礎的検討 ${ }^{2)}$ では, 薬効評価の点で16～70歳の間は同一条件と考えてよらと 
表 6-1 患者背景（1）年令分布

NA 2g 3日間治療群

\begin{tabular}{|c|c|c|c|c|c|c|c|}
\hline 年令 & $16 \sim 19$ & $20 \sim 29$ & $30 \sim 39$ & $40 \sim 49$ & $50 \sim 59$ & $60 \sim 69$ & 計 \\
\hline \hline NA群 & $2(2.2)$ & $21(23.3)$ & $19(21.1)$ & $17(18.9)$ & $18(20.0)$ & $13(14.5)$ & 90 \\
\hline 再発観察群 & $6(4.3)$ & $34(24.5)$ & $43(30.9)$ & $19(13.7)$ & $16(11.5)$ & $21(15.1)$ & 139 \\
\hline 計 & $8(3.5)$ & $55(24.0)$ & $62(27.1)$ & $36(15.8)$ & $34(14.8)$ & $34(14.8)$ & 229 \\
\hline
\end{tabular}

NA 2g7日間治療群

\begin{tabular}{|c|c|r|r|r|r|r|c|}
\hline \hline NA群 & $1(3.8)$ & $8(30.8)$ & $6(23.1)$ & $4(15.4)$ & $5(19.2)$ & $2(7.7)$ & 26 \\
\hline 再発観察群 & $0(0)$ & $7(25.9)$ & $6(22.3)$ & $7(25.9)$ & $5(18.5)$ & $2(7.4)$ & 27 \\
\hline 計 & $1(1.9)$ & $15(28.3)$ & $12(22.6)$ & $11(20.8)$ & $10(18.9)$ & $4(7.5)$ & 53 \\
\hline
\end{tabular}

NA 2g (3日間十7日間)治療群

\begin{tabular}{|c|c|c|c|c|c|c|c|}
\hline \hline N A群 & $3(2.6)$ & $29(25.0)$ & $25(21.6)$ & $21(18.1)$ & $23(19.8)$ & $15(12.9)$ & 116 \\
\hline 再発観察群 & $6(3.6)$ & $41(24.7)$ & $49(29.5)$ & $26(15.7)$ & $21(12.7)$ & $23(13.9)$ & 166 \\
\hline 計 & $9(3.2)$ & $70(24.8)$ & $74(26.2)$ & $47(16.7)$ & $44(15.6)$ & $38(13.5)$ & 282 \\
\hline
\end{tabular}

表 6-2 患者背景（2）膀腅炎の既往（過去 1 年間）

NA 2g3日間治療群

\begin{tabular}{|c|c|c|c|c|}
\hline \multirow{2}{*}{} & \multicolumn{2}{|c|}{ 膀胱炎の既往 } & \multicolumn{2}{c|}{ 既往回数 } \\
\cline { 2 - 5 } & 無 & 有 & 1 回 & 2 回以上 \\
\hline \hline N A群 & $58(64.4)$ & $32(35.6)$ & $20(62.5)$ & $12(37.5)$ \\
\hline 再発観察群 & $97(69.3)$ & $43(30.7)$ & $31(72.1)$ & $12(27.9)$ \\
\hline \multicolumn{3}{|c|}{ (N.S.) 不明 3 } & (N.S.)
\end{tabular}

NA 2g 7 日間治療群

$\chi^{2}$ NA群膀胱炎の既往 無 有

\begin{tabular}{|c|c|c|c|c|c|c|}
\hline NA群 & $22(84.6)$ & $4(15.4)$ & $2(50.0)$ & $2(50.0)$ & NA 2g 3日間治療群 58 & 32 \\
\hline 再発観察群 & $17(63.0)$ & $10(37.0)$ & $9(90.0)$ & $1(10.0)$ & NA 2g 7日間治療群 22 & 4 \\
\hline
\end{tabular}

NA 2g (3日間+7日間)治療群

\begin{tabular}{|c|r|r|r|r|}
\hline \hline N A群 & $80(69.0)$ & $36(31.0)$ & $22(61.1)$ & $14(38.9)$ \\
\hline 再発観察群 & $114(68.3)$ & $53(31.7)$ & $40(75.5)$ & $13(24.5)$ \\
\hline 計 & $194(68.6)$ & $89(31.4)$ & $62(69.7)$ & $27(30.3)$ \\
\hline \multicolumn{5}{|c}{ (N.S.) 不明 4 }
\end{tabular}

表 6-3 患者背景（3）起炎菌分離状況

NA 2g 3日間治療群

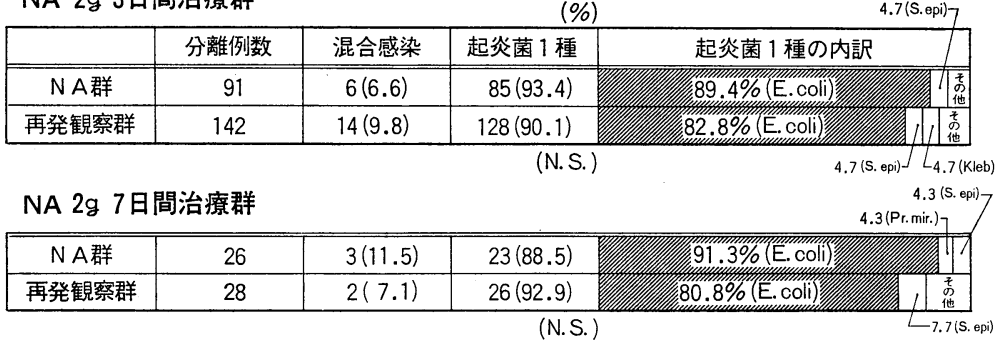

NA 2g (3日間+7日間)治療群

\begin{tabular}{|c|c|c|c|c|}
\hline N A群 & 117 & $9(7.7)$ & $108(92.3)$ & 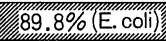 \\
\hline 再発観察群 & 170 & $16(9.4)$ & $154(90.6)$ & 82. $5 \%$ (E.coli) $=$ \\
\hline 計 & 287 & $25(8.7)$ & $262(91.3)$ & 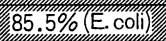 \\
\hline
\end{tabular}


の結果が出ているので，特に問題にはならぬと思われ る.

これら606例の内 592 症例については，過去 1 年内の膀 脱炎の既往についての統計が得られ，約 $7: 3$ で 1 年以 内の罹患既往ののないものが多かつたが，4回以上の罹 患歴のある者も，5例及とめられた。

起炎菌については 1 種のみが認められた549例につい て検査データが得られ，約 $80 \%$ E. coli によるもの であつた。

\section{2) NA の薬効評価について}

606例のらち, 判定日のずれ, 検査の欠落のある176例 を除いた残りの430例について判定すると，表 7 の総計 の欄に 示された如く著効 258 例 $60.0 \%$ ，有効 110 例 25.6
表 7 UTI 基準による評価（430例）

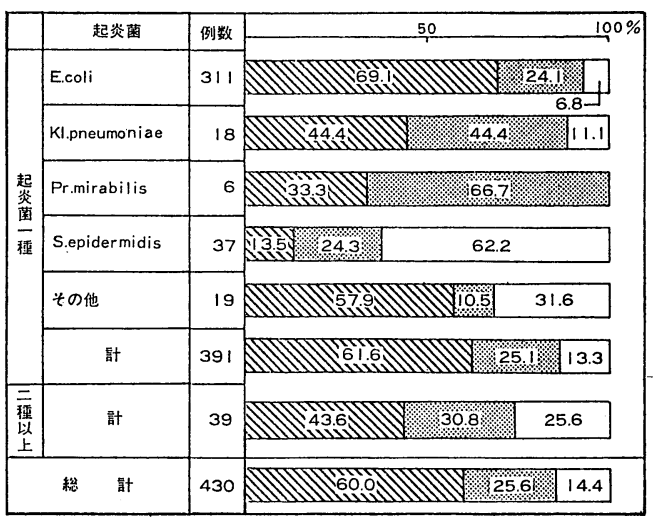

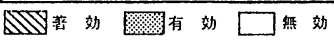

表 8 主治医判定

\begin{tabular}{c|c|c|c|c|c|c|c|c|c|c}
\hline \multirow{2}{*}{ 例数 } & \multicolumn{2}{|c|}{ 著 効 } & \multicolumn{2}{|c|}{ 有 効 } & \multicolumn{2}{|c|}{ やや有効 } & \multicolumn{2}{|c|}{ 無 効 } & \multicolumn{2}{|c}{ 不 明 } \\
\cline { 2 - 11 } & 例数 & $\%$ & 例数 & $\%$ & 例数 & $\%$ & 例数 & $\%$ & 例数 & $\%$ \\
\hline 740 & 397 & 53.6 & 182 & 24.6 & 50 & 6.8 & 84 & 11.4 & 27 & 3.6 \\
\hline & \multicolumn{3}{c|}{$629(85.0 \%)$} & & & & \\
\hline & \multicolumn{3}{c|}{$579(78.2 \%)$} & & & & & \\
\hline
\end{tabular}

\%，無効62例14.4\%であつた. 各菌種別に見ると，起炎 菌一種の場合には，E. coli による症例が311例でその内 著効率は約70\%であり，著効と有効を加えた有効率は

表 9 副作用発現例数（発現率）

\begin{tabular}{c|c|c}
\hline 副作用検討 & あり & な \\
\hline 792 例 & $20(2.5 \%)$ & $772(97.5 \%)$ \\
\hline
\end{tabular}

表10 副作用のための投与中止例

\begin{tabular}{|c|c|c|}
\hline 年 齢 & 症状（程度） & 発現日 \\
\hline 37歳 & 心窩部痛 & 3 日目 \\
\hline 45 歳 & *悪心・呕吐 (十) & 8 日目 \\
\hline 49歳 & $\begin{array}{c}\text { *全身紅斑及㾂痒感 } \\
(+)\end{array}$ & 1日目 \\
\hline 52歳 & 呕気 (H) & 2 日目 \\
\hline 年 齢 & 症状（程度） & 発現日 \\
\hline 31歳 & *胃部疼痛 & 2 日目 \\
\hline 16歳 & *めまい（H） & 3 日目 \\
\hline 44歳 & $\begin{array}{c}\text { 頭頭痛・心悸六進，手 } \\
\text { 足しびれ感 }\end{array}$ & 1日目 \\
\hline
\end{tabular}

$*$ 薬剂との関係不明
93.2\%である. K. pneumoniae P. mirabilis 飞は著効率 は50\%を割るが，有効率は80\%以上である。しかし S. epidermidis については有効率は半分以下であつた.

2 種以上の細菌の混合感染例に使用した症例は37あ

り，43.6\%の著効， $30.8 \%$ の有効，有効率 $74.4 \%$ であつ

表11 副作用の種類・発生件数

\begin{tabular}{|c|c|c|}
\hline \multirow{2}{*}{ 種 } & \multicolumn{2}{|c|}{ 発生数 } \\
\hline & 件数 & $\begin{array}{l}\text { 発生率 } \\
(\%)\end{array}$ \\
\hline 気・悪 & 3 & 0.4 \\
\hline 食 欲 不 振 & 1 & 0.1 \\
\hline 胃 部 不 快 感 & 6 & 0.7 \\
\hline 腹 & 3 & 0.4 \\
\hline ふらふら感，めまい感 & 3 & 0.4 \\
\hline 頭 & 2 & 0.3 \\
\hline 皮席発赤・痹痒 & 1 & 0.1 \\
\hline 発 & 1 & 0.1 \\
\hline 心 悸 京 進 & 1 & 0.1 \\
\hline 手足しびれ & 1 & 0.1 \\
\hline 計 & 22 & \\
\hline
\end{tabular}


た.

7 日間連続 して NAを投与した群53例では著効 47 , 有効 5 , 無効 1 で, 有効率 $98.1 \%$ となつた（中部ブロッ ク症例).これは 3 日目判定の 有効率 $81.1 \%$ や，4 日目 判定の有效率 $85.0 \%$ より有意倍高い。

表 8 に主治医による判定を記した. 713例に 判定が行 われており，著効，有効を合わせた有効率は78.2\%であ つた。この判定は主治医の主観によるもので，評価基準 は統一されていない。

4）副作用

808例中，自覚的副作用の発現の有無を記載したもの は792例であり，内20例 $(2.5 \%)$ に副作用が出現してい
る(表 9 ).

副作用の内容と発現日を表10に示した，その内 4 例は 主治医のコメントによれば，薬剤との 関係は不明であ る.

表11亿副作用の種類，発生件数，発生率を示した。胃 腸障害が主である。

5) 再発

規定にしたがつて 3 日分投与され UTI 基準にり著効 と判定された258例について，再発を検討するに足る資 料が 得られたのは167例であり，他は何等かの理由で脱 落となつた．その大部分は検査日のずれ，検査項目の欠 落，再受詮せず，等であつた（表 4-2）.

表12 NA $2 \mathrm{~g} 3$ 日間治療による著効例の再発と NA $1 \mathrm{~g}$ による再発抑制

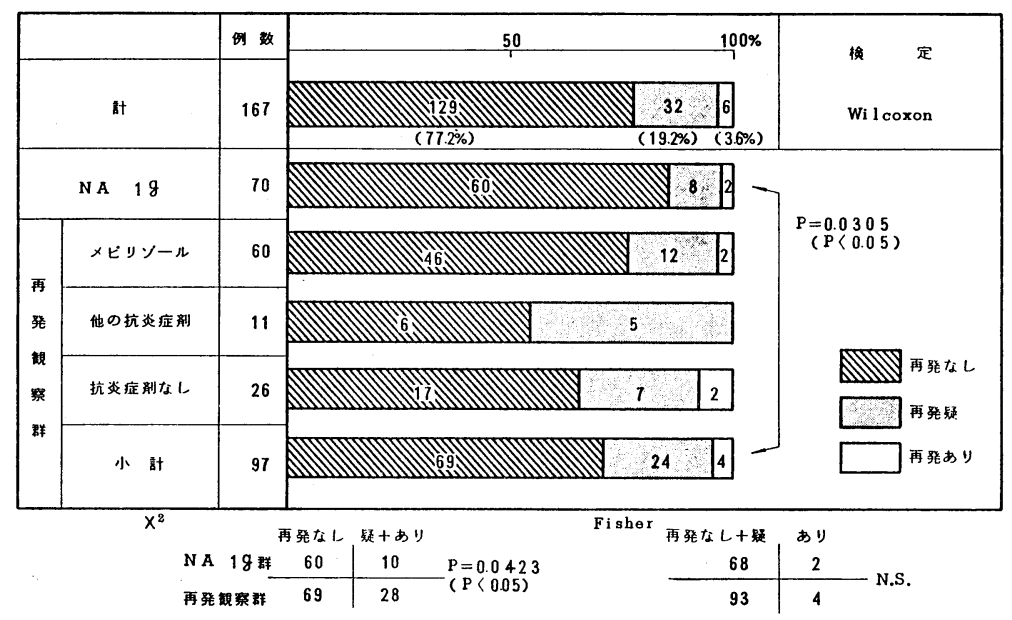

表13 NA 2 g 3 日間治療による著効例の再発と NA $1 \mathrm{~g}$ による再発抑制 一起炎菌一種のみの症例一

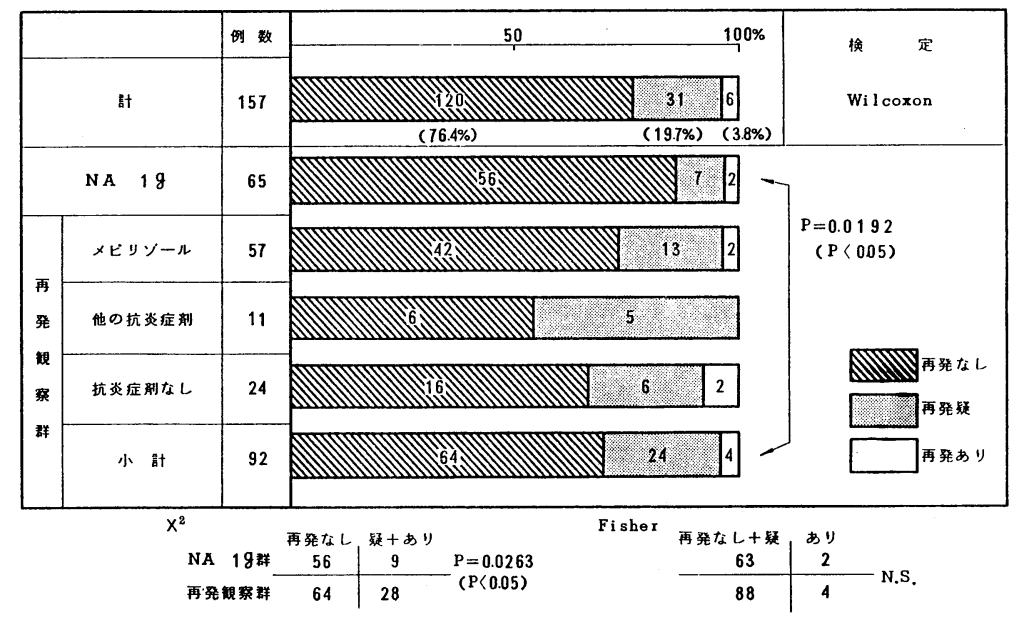


この内，明らかな再発を起こした症例は 6 例，3.6\% であつた。この他に完全な再発とはみとめられ妨，少 数の細菌を検出したり, 白血球のみを検出したり等の, 完全な正常状態ではないとみとめられる症例が32例，19 $.2 \%$ あ,これらの症例をここでは便宣上再発疑群と呼 ぶことにする。再発と再発疑を合計すると38例であり, $22.8 \%$ に当たる (表12).これらを既述の如く, NA 3 日分投与後, 抗炎症剂投与群, 無投与群, NA $1 \mathrm{~g}$ 投与 群にわけて検討すると, 抗炎症剂投与群のらち, メピリ ゾール投与群 60 例からは 2 例, 他の抗炎症剂投与群 11 例 からは0 例, 無投与群26例からは2 例の 再発であった が, 再発疑はメピリゾール投与群では12例, 他の抗炎症. 剂投与群では 5 例, 無投与群では 7 例であつた.

他の抗炎症剤の投与されている場合は, 薬剂も投与量 もまちまちであり，中には単独で膀脱炎に対して治療効 果ありとされている薬剤を投与している例もあったが, メピリゾール $100 \mathrm{mg}$ 投与群と比較して, 効果に有意の 差をみとめないので，以後同一に扱らことにした。

ここで, 再発なし及び再発疑を規定の如く再発なしと し，再発の規定に合つた 6 症例をありとして，各群間の 再発率の差をみると, NA 投与の 70 例と, 非投与の 97 例 間に有意の差はみとめられない。しかしながら，「再発 疑十再発」群としてまとめると，3 日間治療後 NA1g 投 与群の方が, NA 非投与群より「再発疑十再発」群の数 が有意に少なかつた。

複数菌感染例を除き, 起炎菌一種のみの症例について 同様にまとめてみたのが表13である.157例について， 6 例の再発がみとめられた。つまりここで除いた10例の 複数菌感染例は NA $2 \mathrm{~g}$ による治癒後の再発はなかつた といらことになる.

治療後 NA $1 \mathrm{~g}$ 投与群と, その他の方法による経過観 察群の間に Fisher の検定法により再発に関して差はみ とめられない。しかし, 表12の場合と同様に, 「再発十 再発疑」を⿱とめて考光ると, NA $1 \mathrm{~g}$ 投与群の方が, その他の方法による経過観察群よりも有意に少なかつ た. 即ちこの 2 群間の差は, 再発の差よりもむしろ再 発疑とされる症例群の数の差で現われてくるものといえ よう.

表14に，完全な再発をみとめられた 6 例の治療前後及 び再発時の検査結果を一覧表にして示した.すべて起因 菌は, E. coli であり, 再発時もすべて E. coli が含 まれている，同一の血清型の菌であるか否かまでは検討 していないが，ディスク感受性から類推すると, 前後

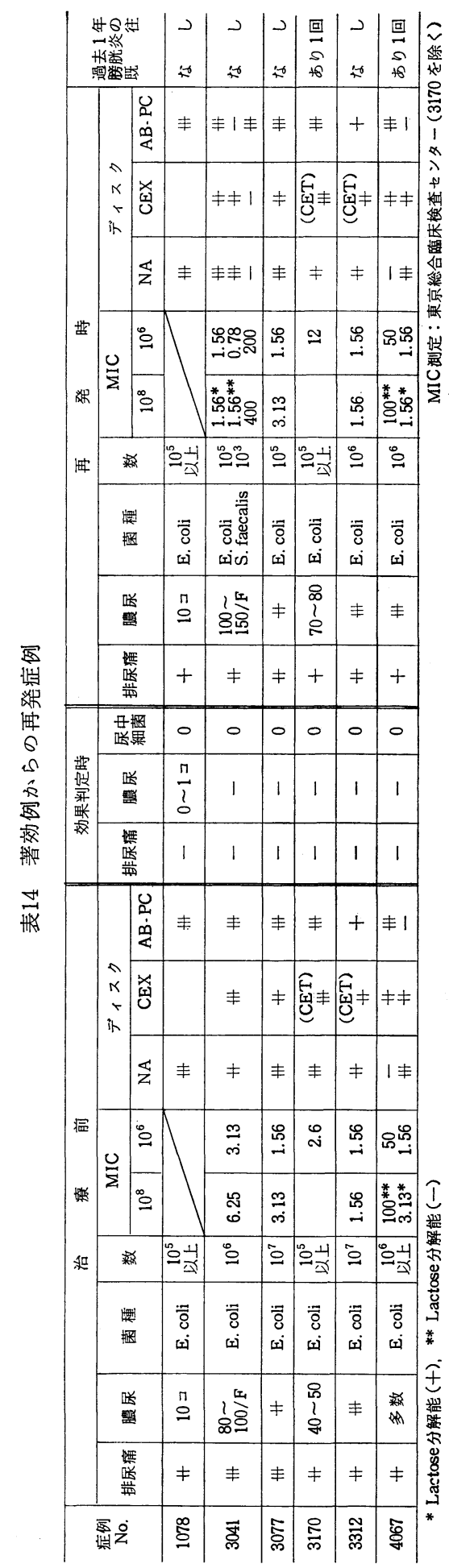


共, 同一の菌によつて起こつているものと推定される.

6）有効例の再発

UTI 薬効評価基準では，著効と有効をまとめて有効 率を算出することになつている．ここで有効例といらの はそれから著効を除いたもの，つまり有効と判定された 例の女を集めてみて，それがその後いかなる経過をとつ たかの検討である（表15）.

NA 2g 3 日間投与後, 有効と判定された症例は66例 である.これらから再発と判定された症例は 5 例に2と められた. 治療後 NA $1 \mathrm{~g}$ 投与群の 21 例からはみとめら れず，その他の方法による経過観察群45例の中からのみ
みとめられた。統計的には Wilcoxon の検定によりそそ の他の方法による経過観察群の方に NA $1 \mathrm{~g}$ 投与群より も，再発が有意に多かつたと言える.

しかしこの場合 $\mathrm{X}^{2}$ 検定により再発疑と再発をまと めて統計処理すると，両群間に差はない。つまり 3 日間 の治療後には有効と判定された症例でさらに 7 日後には 「著効」と判定されるような状態になつている症例の率 は NA $1 \mathrm{~g}$ 投与でもその他の方法による経過観察群との 間に差がないと言うことができる．同様に「再発なし」 と「再発疑」を加光て，「あり」と比較しても，両群間 に差はみとめられない。

表15 NA $2 \mathrm{~g} 3$ 日間治療による有効例の再発と NA $1 \mathrm{~g}$ に上る再発抑制

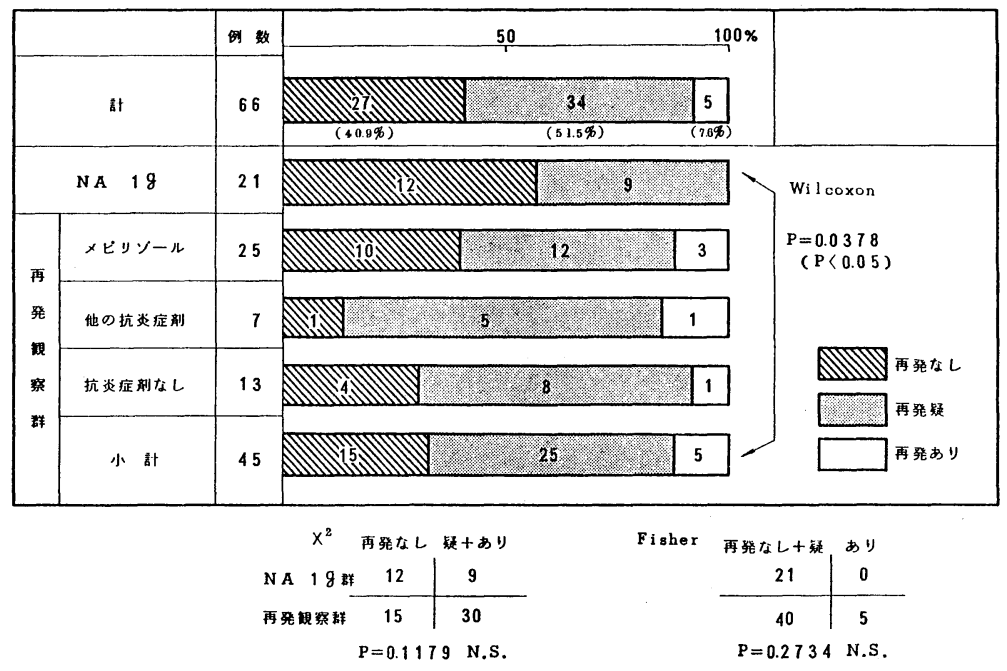

表16 NA $2 \mathrm{~g} 3$ 日間治療による有効例の再発と NA $1 \mathrm{~g}$ による再発抑制 一起炎菌一種, 2 種以上別一

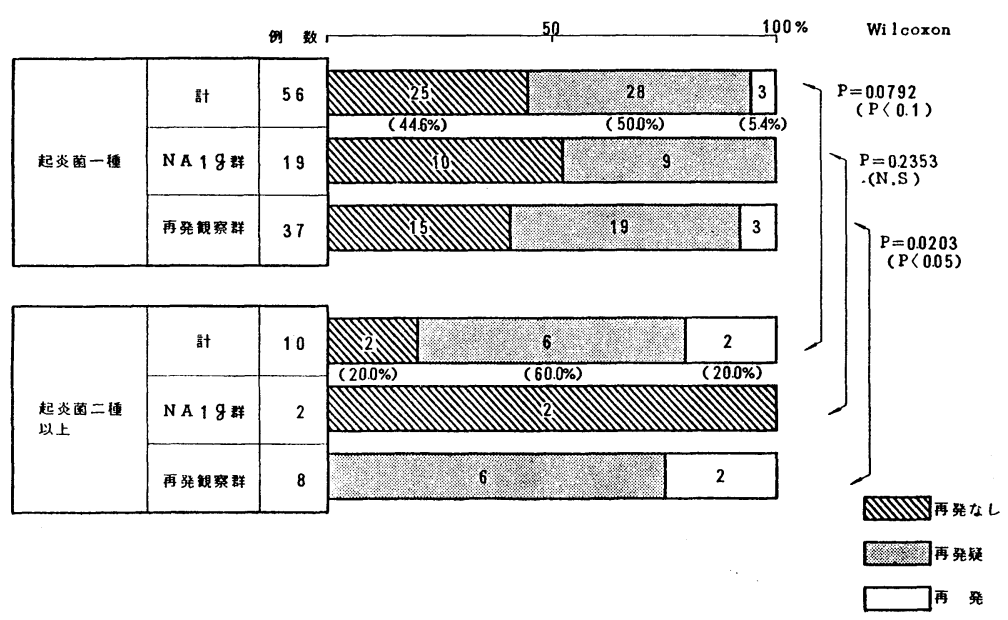


表17 NA 2 g 3 日間治療による著効例, 有効例の 再発一NA $1 \mathrm{~g}$ の継続投与例を含む一

\begin{tabular}{|c|c|c|c|c|c|}
\hline & 例数 & 再発なし & 再発疑 & 再発あり & $\begin{array}{c}\text { 検 定 } \\
\text { Wilcoxon }\end{array}$ \\
\hline 著効例 & 167 & $129(77.2)$ & $32(19.2)$ & $6(3.6)$ & \multirow{2}{*}{$\begin{array}{l}p=0.0000 \\
(p<0.001)\end{array}$} \\
\hline 有効例 & 66 & $27(40.9)$ & $34(51.5)$ & $5(7.6)$ & \\
\hline
\end{tabular}

Fisher 再発なし十疑 あり

$$
\begin{array}{r|r}
\hline 161 & 6 \\
\hline 61 & 5 \\
\hline
\end{array}
$$

表16には，有効之判定された症例の起炎菌 1 種のもの と 2 種のものを区別して記してある. 3 種以上の症例は なかつた。

起炎菌 1 種の56例は, 再発 3 例 $5.4 \%$ で, 2 種の 10 例 は，2 例 $20 \%$ である. 起炎菌 1 種群は 2 種群より再発が 少ない傾向がうかがわれた $(p=0.0792)$.

またその内容を NA $1 \mathrm{~g}$ 投与群と, その他の方法によ る経過観察群にわけて処理してみると, その他の方法に よる群については, 起炎菌 2 種群の方が 1 種群よりも, 有意に再発が多いことが知られた。

またNA $2 \mathrm{~g} 3$ 日間投与後に有効と判定され，さらに 7 日目の再発検討時に「著効」といえるような正常状態 に戻つている例は, 起炎菌 1 種群では56例中25例であつ たが，2種群では10例中 2 例で㐫り, 統計的に 1 種群に 多い傾向がみとめられた $(\mathrm{p}=0.0792)$. しかし NA $1 \mathrm{~g}$ 投与群とその他の方法による経過観察群の間には差はみ とめられなかつた。

表17に，NA $2 \mathrm{~g} 3$ 日間投与後に著効と判定された 167 例と, 有効と判定された66例についてのその後 7 日目, つまり投薬開始日から10日目の結果をまとめてみた。再 発は明らかに著効例よりも有効例に多い。また10日目に 再発なしと判定された症例も有効例には少なく，著効例 の方に多い。しかし「再発なし」と「再発疑」を加えて

表18 NA 2 g 3 日間治療による著効例, 有効例の 再発一その他の方法による再発観察群一

\begin{tabular}{|c|c|c|c|c|c|}
\hline & 例数 & 再発なし & 再発疑 & 再発あり & $\begin{array}{l}\text { 検 定 } \\
\text { Wilcoxon }\end{array}$ \\
\hline 著効例 & 97 & $69(71.1)$ & $24(25.8)$ & $4(4.1)$ & \multirow{2}{*}{$\begin{array}{l}p=0.0000 \\
(p<0.001)\end{array}$} \\
\hline 有効例 & 45 & $15(33.3)$ & $25(55.6)$ & $5(11.1)$ & \\
\hline \multicolumn{6}{|c|}{$\chi^{2}$ 再発なし十疑 あり } \\
\hline & 93 & 4 & & & \\
\hline & 40 & 5 & & & \\
\hline & 0.22 & 70 N.S. & & & \\
\hline
\end{tabular}

「あり」として $\mathrm{X}^{2}$ 検定により比較すると著効例群， 有効例群に差がなかつた。

NA 2g 3 日間治療後，NA を投与しなかつた症例， つまりこれまで「その他の方法による経過観察群」の名 で呼んで来た症例を，表18にまとめた。著効97例と有効 表19 有効例の検討. 効果判定時残存症状, 所見の 分析

I. 1要因分析

\begin{tabular}{|c|c|c|}
\hline \multicolumn{3}{|c|}{ 尿 中 細 菌 } \\
\hline & 0 & 51 例 \\
\hline \multicolumn{2}{|c|}{$<10^{3}$} & 22 \\
\hline \multicolumn{2}{|c|}{$\geqq 10^{3}$} & 37 \\
\hline \multicolumn{2}{|r|}{ 膿 } & \\
\hline \multicolumn{2}{|c|}{$0 \sim 4$} & 61 例 \\
\hline \multirow[t]{2}{*}{ あ } & り & 49 \\
\hline & 排 & \\
\hline な & L & 79 例 \\
\hline あ & り & 31 \\
\hline
\end{tabular}

尿中細菌の残存が多く次いで膿尿，排尿痛の 順である。

II. 2要因分析

\begin{tabular}{c|c|c|}
\hline \multirow{2}{*}{ 尿細菌 } & \multicolumn{2}{|c}{ 膿 } \\
\cline { 2 - 3 } & $0 \sim 4$ & 尿 \\
\hline 0 & 12 & 39 \\
\hline$<10^{3}$ & 17 & 5 \\
\hline$\geqq 10^{3}$ & 32 & 5 \\
\hline
\end{tabular}

\begin{tabular}{c|c|c|}
\hline \multirow{2}{*}{ 尿細菌 } & \multicolumn{2}{|c}{ 排 尿 痛 } \\
\cline { 2 - 3 } & なし & あ り \\
\hline 0 & 32 & 19 \\
\hline$<10^{3}$ & 17 & 5 \\
\hline$\geqq 10^{3}$ & 30 & 7 \\
\hline
\end{tabular}

\begin{tabular}{c|c|c}
\hline \multirow{2}{*}{ 排㽷痛 } & \multicolumn{2}{|c}{ 膿 } \\
\cline { 2 - 3 } & $0 \sim 4$ & 尿 \\
\hline な し & 40 & 39 \\
\hline あ & 21 & 10 \\
\hline
\end{tabular}

内は両者とも残存している症例 
表20 有効例の再発要因一一要因分析一

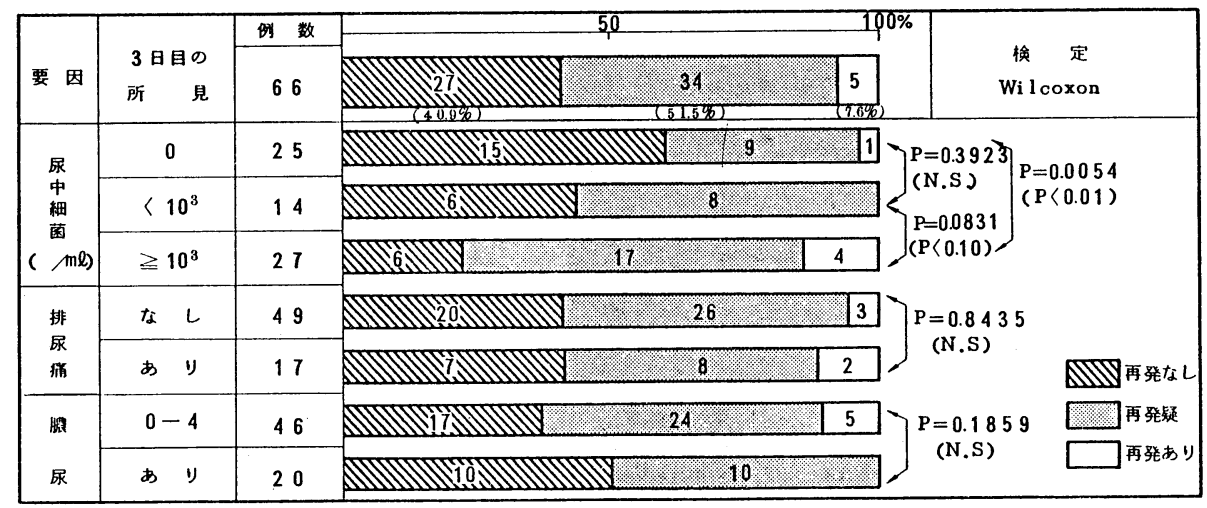

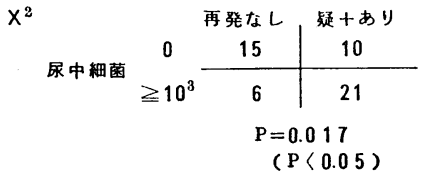

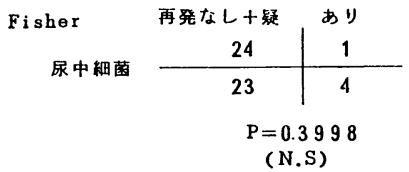

45例に分けて検討すると，やはり再発は有効例に多く， 再発なしは有效例に少ないといら，表17 と同じ傾向がみ とめられる。

NA 2g 3 日間投与後の 効果判定時に 著効でなく有効 と判定された症例が，何故有効とされて著効とされなか つたか，その原因を一覽表にしたのが表19である，UTI 薬効評価基準では, 著効と判定されるためには，尿中 細菌数 0 , 排尿痛なし, 膿尿 $0 \sim 4$ ב/hpf の条件をみ たしていなければならない.110例の有効例について分 析すると，尿中細菌数が不变であつたもの37例，減少 22 例であり，膿尿が正常化しなかつたもの 49 例，排尿痛の 残存したもの 31 例であつた。ささにこれら 2 要因ずつの 組み合わさつた症例を検討してみると, 細菌の減少と膿 尿残存が 5 例, 細菌不変と膿尿残存も 5 例, 細菌減少と 排尿痛が 5 例, 細菌不変之排尿痛が 7 例, 膿尿と排尿痛 の組み合わせが10例となり，尿中の細菌残存と排尿痛の あるため, 膿尿が改善しても著効にならなかつたという 症例が計12例で最多であつた.

この各々の要因別に，その後 7 日目の状態がぞのよう であつたかを表20に示してある。これによると，NA $2 \mathrm{~g}$ 3 日間投与後に尿中細菌が不変であつた症例からの再発 は，0となつた症例よりも再発が有意に多くなつてい る. 具体的に言光ば，27例中 4 例の再発をみとめ, 17例 が再発疑，6例が再発なしであるのに対し，0 の25例で は 1 例の再発, 9 例の再発疑, 15 例が再発なしである.
再発疑と再発を加えたるのと再発なしとを比較すると， その差はさらに明らかになり, 尿中細菌不変のものに再 発なしが尿中細菌 0 のものより少ないことがわかる.排 尿痛のあり。なしと，膿尿のあり，正常化の別は，再発 率に関しては差がないことが知られた。

表21一23には，2つの要因ごとの組合わせで行つた有 効と判定された症例の，その後の成り行きをまとめたも のを記した．これらの表から考光て，完全な再発に関し ては，どの要因も優位に関連していない. 即ち, 特定の 2 つの要因の重なつたものが再発に至りやすいといら傾 向は見られない。

表24には，効果判定時に有効と判定され，その後 7 日 目に再発と判定された 7 症例の 検査結果を一覧表にし た. 7 例中 5 例は判定後に菌を検出している.しかしな がら治療前後及び再発時の菌種が同じといらのは 1 例し かなく, 治療前後に共通菌を検出したと思われる例は 5 例で，表14の著効から再発した症例とはかなり異なつた 傾向をみとめ，再然を思わせる例と再感染を思わせる例 とが約半分ずつとなつているよらである.

7）薬剤使用期間と再発

NA $2 \mathrm{~g}$ を 3 日間投与した後, さらに7日間 NA $1 \mathrm{~g} 1$ 回のみの投与を持続した70例と，その他の方法による経 過観察例97例を比較してみた。さらに NA $2 \mathrm{~g}$ を 7 日投 与後さらに $1 \mathrm{~g}$ を 7 日与えた群と，NA $2 \mathrm{~g} 7$ 日投与後経 過を観察した群が各々26例，28例あり，これらもまとめ 
表21 有効例の再発要因一二要因分析一

\begin{tabular}{|c|c|c|c|c|c|c|c|c|c|}
\hline 原中相菌 & \multicolumn{3}{|c|}{0} & \multicolumn{3}{|c|}{$<10^{3}$} & \multicolumn{3}{|c|}{$\geqq 10^{3}$} \\
\hline \multirow{4}{*}{$0-4$} & $\begin{array}{l}\text { 再発 } \\
\text { なし }\end{array}$ & 铰 & कり & 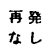 & 翡 & कり & 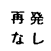 & 短 & कण \\
\hline & 6 & 2 & 1 & 5 & 7 & 0 & 6 & 15 & 4 \\
\hline & \multirow{2}{*}{\multicolumn{3}{|c|}{$\pi$}} & & & & & গ & \\
\hline & & & & $i 1 \cos$ & $P$ & 1.0592 & $(\mathrm{P}<0$ & & \\
\hline \multirow{3}{*}{ क } & 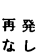 & 翨 & का & $\begin{array}{l}\text { 再発 } \\
\text { 生し }\end{array}$ & 㓋 & あり & 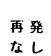 & 疑 & कり \\
\hline & 9 & 7 & 0 & 1 & 1 & 0 & 0 & 2 & 0 \\
\hline & \multicolumn{9}{|c|}{ Wilcoxon N.S. } \\
\hline
\end{tabular}

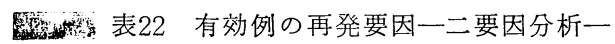

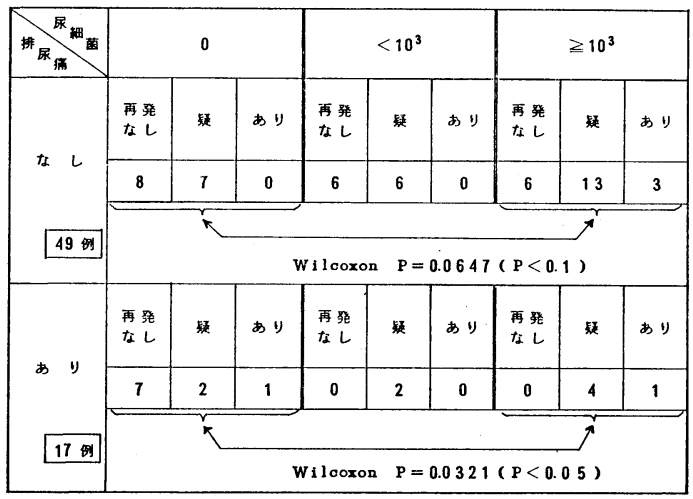

表23 有効例の再発要因一二要因分析一

\begin{tabular}{|c|c|c|c|c|c|c|}
\hline 排尿痛 & \multicolumn{3}{|c|}{ なし } & \multicolumn{3}{|c|}{ あり } \\
\hline \multirow{2}{*}{$0 \sim 4$} & $\begin{array}{l}\text { 再発 } \\
\text { なし }\end{array}$ & 疑 & あり & $\begin{array}{l}\text { 再発 } \\
\text { なし }\end{array}$ & 疑 & あり \\
\hline & 11 & 16 & 3 & 6 & 8 & 2 \\
\hline 46例 & \multicolumn{6}{|c|}{$\begin{array}{c}\text { Wilcoxon N.S. } \\
\mathrm{p}=0.9693\end{array}$} \\
\hline \multirow{3}{*}{$\begin{array}{l}\text { あ り } \\
20 \text { 例 }\end{array}$} & $\begin{array}{l}\text { 再発 } \\
\text { な }\end{array}$ & 疑 & あり & $\begin{array}{l}\text { 再発 } \\
\text { なし }\end{array}$ & 疑 & あり \\
\hline & 9 & 10 & 0 & 1 & 0 & 0 \\
\hline & \multicolumn{6}{|c|}{$\begin{array}{c}\text { Wilcoxon N.S. } \\
p=0.3681\end{array}$} \\
\hline
\end{tabular}

て表25に示してある.ここにのせてあるのは 3 日間内服 で著効と判定された，又は 7 日間服用した時点での検查 結果が UTI 薬效評価基準の中の用語を用いれば「著 効」と判定できる状態であつた症例のみである.

NA $2 \mathrm{~g} 3$ 日間の投与例では, その後 NA $1 \mathrm{~g}$ を 7 日間

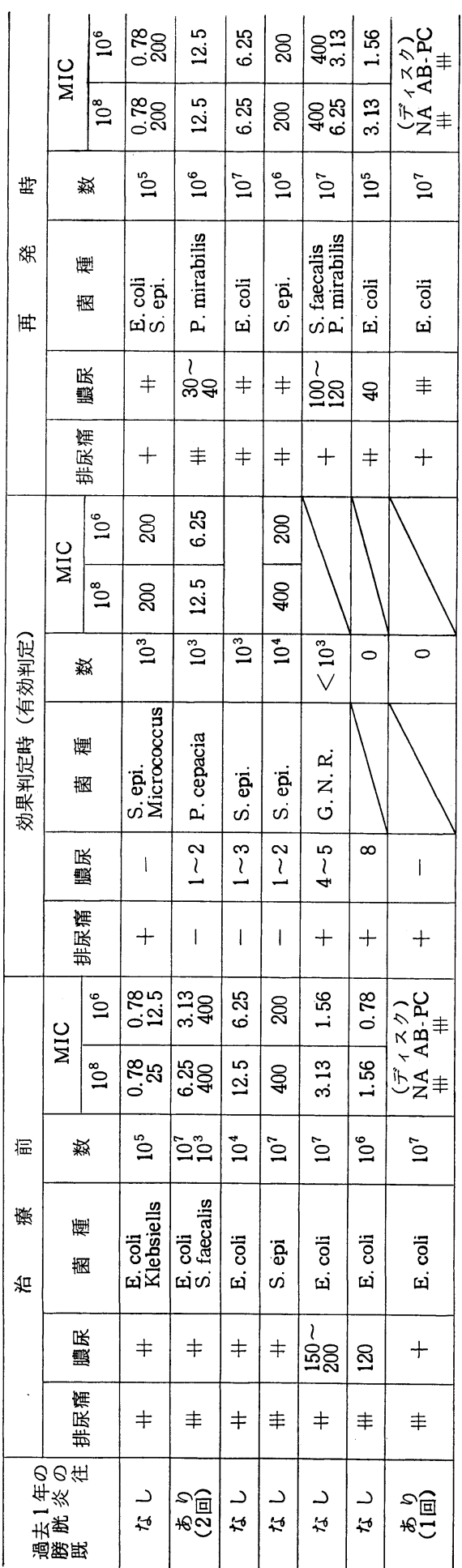


投与した群から 2 例，その他の方法による経過観察群か ら 4 例の再発があり, 再発に関しては統計的に有意差が ないが「再発十再発疑」としてまとめると NA $1 \mathrm{~g}$ が有 意に少ない $(p=0.0305)$.

NA $2 \mathrm{~g}$ を 7 日間投与した症例についても，その後の 再発率は NA $1 \mathrm{~g}$ をさらに 7 日間投与した群（即ち合計 2 週間に NA $21 \mathrm{~g}$ を投与した群）と，その他の方法に よる経過観察群の間に，再発率の差はみとめられない。

しかしながら，その他の方法による経過観察群につい てみると，NA $2 \mathrm{~g} 3$ 日間投与例よりも， NA 2g 7 日間 投与例の方が「再発十再発疑」で有意に少なかつた $(\mathrm{p}$ $=0.0235$ ).

8） NA $1 \mathrm{~g}$ 連続投与と再発

NA $2 \mathrm{~g} 3$ 日間投与後の 尿中細菌数別による再発の有
無を，NA 1g 7 日間追加投与群とその他の方法による 経過観察群にわけて検討してみた（表26）. 各々の群の 症例数が少なくなつているので, 参考としてのみの意義 しかない。

NA 1 g 7 日間追加投与群とその他の 方法による 経過 観察群の各々の群の中で, 判定時の細菌数別による, そ の後の再発率の差があるか否かを検討したのが表26の下 に附した表である。これによると，その他の方法による 経過観察群の中で, 判定時尿中細菌数 0 であつた，19症 例の再発は, 判定時尿中に細菌をみとめた 26 症例掞よび その中でも $10^{3}=/ \mathrm{ml}$ 以上みとめた 18 症例の 再発と比較 すると，有意に少ない。つまり NA $2 \mathrm{~g} 3$ 日間投与後, NA $1 \mathrm{~g}$ を追加投与しない場合は，尿中に 細菌の残存が あれば再発の危険率が高いといら結果が得られた。

表25 薬剤使用期間別の再発の検討一著効例一

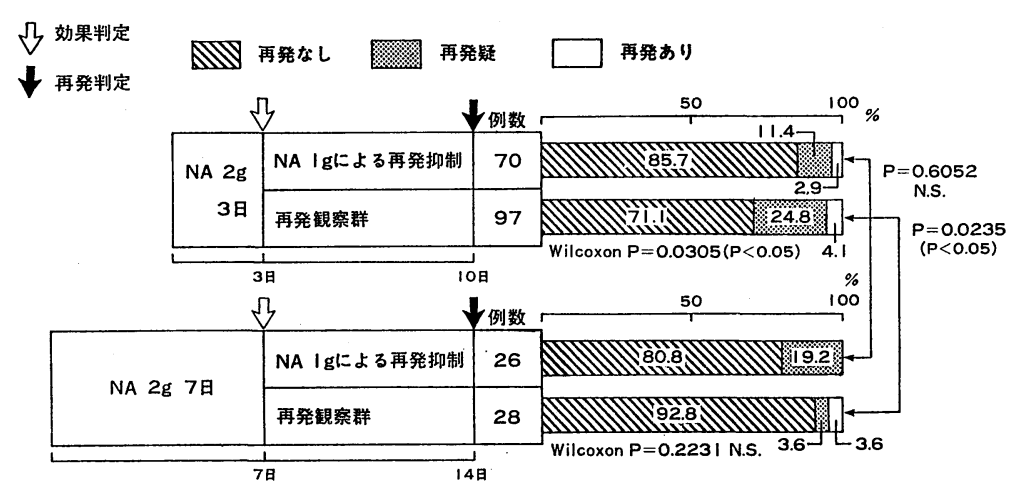

表26 有効例の再発一尿中細菌の残存と再発

\begin{tabular}{|c|c|c|c|c|c|c|c|}
\hline & 艮中細菌 & 例 & 再 発 な し & 再 & 発 疑 & 再 叱 あ & 愌 \\
\hline \multirow{4}{*}{ NA $1 \mathrm{~g}$ 群 } & 0 & 6 & $4(66.7)$ & 2 & $(33.3)$ & \multirow{2}{*}{0} & \multirow{2}{*}{$\begin{array}{r}P=0.6838 \\
\text { (N.S.) }\end{array}$} \\
\hline & $<10^{3}$ & 6 & $5(83.3)$ & 1 & (16.7) & & \\
\hline & $\geqq 10^{3}$ & 9 & $(33.3)$ & 6 & ( 66.7$)$ & 0 & \multirow{2}{*}{ 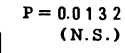 } \\
\hline & it & 21 & $12(57.1)$ & 9 & (42.9) & 0 & \\
\hline \multirow{4}{*}{ 再発钼繁群 } & 0 & 19 & $11(57.9)$ & 7 & ( 36.9$)$ & $1(5.2)$ & \multirow{4}{*}{$\begin{array}{r}P=0.1342 \\
\quad \text { (N.S.) }\end{array}$} \\
\hline & $<10^{3}$ & 8 & $1(12.5)$ & 7 & ( 87.5$)$ & 0 & \\
\hline & $\geqq 10^{3}$ & 18 & $(16.7)$ & 11 & ( 61.1$)$ & $(22.2)$ & \\
\hline & st & 45 & $15(33.3)$ & 25 & (55.6) & $5(11.1)$ & \\
\hline
\end{tabular}

\begin{tabular}{|c|c|c|c|c|c|c|c|c|}
\hline & 尿中細菌 & 娭 定 & 尿中梱菌 & 检 定 & 尿中知菌 & 梚 定 & 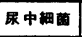 & 怡 定 \\
\hline \multirow{2}{*}{$\begin{array}{l}\text { NA } 1 \text { g群 } \\
\text { の再哞 }\end{array}$} & 0 & \multirow[b]{2}{*}{$\begin{array}{r}P=0.5948 \\
\text { (N.S.) }\end{array}$} & 0 & \multirow[b]{2}{*}{$\begin{array}{r}P=0.2474 \\
\text { (N.S.) }\end{array}$} & 0 & \multirow[b]{2}{*}{$\begin{array}{r}P=0.6178 \\
\text { (N.S.) }\end{array}$} & $<10^{3}$ & \multirow[b]{2}{*}{$\begin{array}{r}P=0.0769 \\
(P<0.1)\end{array}$} \\
\hline & $<10^{3}$ & & $\geqq 10^{3}$ & & $\begin{array}{l}<10^{3} \\
+ \\
\geqq 10^{3}\end{array}$ & & $\geqq 10^{3}$ & \\
\hline
\end{tabular}

\begin{tabular}{|c|c|c|c|c|c|c|c|c|}
\hline \multirow{2}{*}{$\begin{array}{l}\text { 再発観察群 } \\
\text { の再発 }\end{array}$} & 0 & \multirow[b]{2}{*}{$\begin{array}{r}P=0.0656 \\
(P<0.1)\end{array}$} & 0 & \multirow[b]{2}{*}{$\begin{array}{l}P=0.0088 \\
(P<0.01)\end{array}$} & 0 & \multirow[b]{2}{*}{$\begin{array}{c}P=0.0047 \\
(P<0.01)\end{array}$} & $<10^{3}$ & \multirow[b]{2}{*}{$\begin{array}{r}P=0.4734 \\
\text { (N.S.) }\end{array}$} \\
\hline & $<10^{3}$ & & $\geqq 10^{3}$ & & $\begin{array}{l}<10^{3} \\
\quad+ \\
\geqq 10^{3}\end{array}$ & & $\geqq 10^{3}$ & \\
\hline
\end{tabular}


表27 有効例の再発と NA $1 \mathrm{~g}$ にるる再発抑制一「再発寲」症例のらち効果判定時より所見の悪化し た症例のみを「再発疑（悪化）」とし，その他は「再発なし」に加えた時の解析一
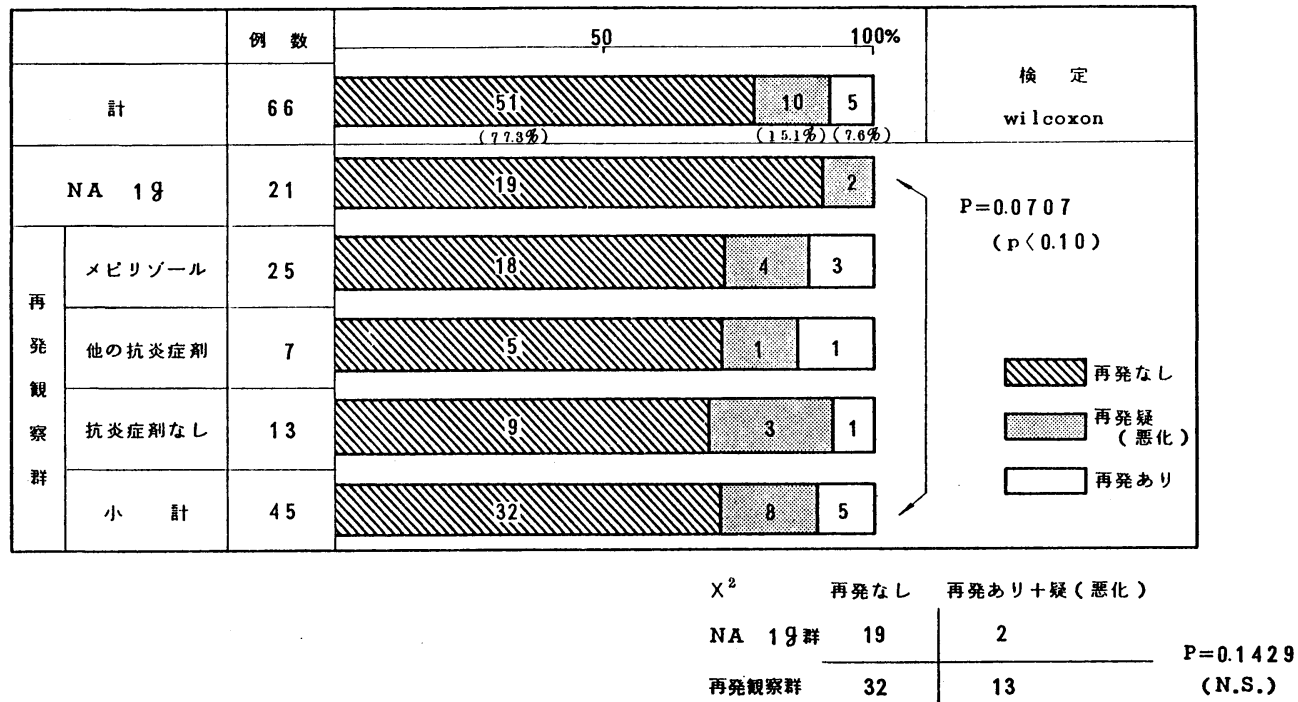

姍28 有効例からの再発疑拈よび再発寲 *

\begin{tabular}{|c|c|c|c|c|c|c|c|c|c|c|c|c|c|}
\hline \multicolumn{3}{|c|}{ 効果判定時 } & \multicolumn{3}{|c|}{ 再発判定時 } & \multirow{2}{*}{$\frac{\text { 備 考 }}{\text { 再発疑＊症例 }}$} & \multicolumn{3}{|c|}{ 効果判定時 } & \multicolumn{3}{|c|}{ 再発判定時 } & \multirow{2}{*}{$\frac{\text { 備 考 }}{\text { 再発疑 } * \text { 症例 }}$} \\
\hline 排尿痛 & 膿尿 & 尿細菌 & 排尿痛 & 膿尿 & 尿細菌 & & 排尿痛 & 膿尿 & 尿細菌 & 排尿痛 & 膿尿 & 尿細菌 & \\
\hline+ & - & 0 & - & - & $10^{2}$ & & - & \pm & 0 & - & \pm & $<10^{3}$ & $*$ \\
\hline- & \pm & $10^{2}$ & - & + & 0 & & - & - & $10^{3}$ & - & - & $10^{3}$ & \\
\hline+ & - & $10^{2}$ & - & - & $10^{2}$ & & - & \pm & 0 & - & + & $<10^{3}$ & $*$ \\
\hline- & - & $10^{4}$ & - & + & $10^{4}$ & $*$ & + & - & $10^{3}$ & - & - & $10^{5}$ & \\
\hline+ & - & $10^{5}$ & - & $H$ & $10^{5}$ & & - & - & $10^{3}$ & - & \pm & $10^{4}$ & $*$ \\
\hline- & - & $<10^{3}$ & + & H & $10^{3}$ & $*$ & - & \pm & $10^{4}$ & - & - & $10^{4}$ & \\
\hline- & - & $<10^{3}$ & - & - & $<10^{3}$ & & + & - & $10^{1}$ & + & \pm & $10^{7}$ & $*$ \\
\hline- & - & $10^{3}$ & - & - & $10^{3}$ & & - & \pm & $10^{3}$ & - & - & $10^{3}$ & \\
\hline- & - & $<10^{3}$ & - & - & $<10^{3}$ & & - & - & $10^{4}$ & + & H & 欠测 & $*$ \\
\hline- & + & 0 & - & \pm & 欠測 & & - & + & 0 & - & \pm & 0 & \\
\hline- & - & $10^{3}$ & - & \pm & $10^{4}$ & $*$ & - & $\mathrm{HH}$ & 0 & - & + & 0 & \\
\hline+ & - & $10^{3}$ & + & + & 欠測 & & - & - & $10^{3}$ & - & - & $10^{3}$ & \\
\hline- & - & $10^{3}$ & - & - & $<10^{3}$ & & - & + & 0 & - & + & $10^{3}$ & $*$ \\
\hline- & - & $10^{3}$ & - & - & $10^{2}$ & & + & - & 0 & + & - & 0 & \\
\hline- & - & $10^{2}$ & - & - & $10^{2}$ & & + & - & $10^{4}$ & - & - & $10^{3}$ & \\
\hline- & \pm & 0 & - & \pm & 0 & & - & - & $<10^{3}$ & - & - & $10^{3}$ & \\
\hline- & - & $10^{3}$ & $\mathrm{H}$ & $H$ & $10^{3}$ & $*$ & - & - & $10^{7}$ & - & - & $10^{7}$ & \\
\hline
\end{tabular}


表27は, 再発疑症例のらち, 効果判定時より症状の悪 化した症例のみを再発疑の濃いものといら意味で「再発 疑*」とし，その他の症例は再発なしに加えたときの解 析である.この表から，NA $2 \mathrm{~g} 3$ 日間投与後さらに NA $1 \mathrm{~g}$ を続けて投与した群と，その他の方法による経過観 察群の間では再発に関しては NA $1 \mathrm{~g}$ 投与群が少ない傾 向を示したが，再発と「再発疑」」を加えたものにつき 検定すると， $\mathrm{p}=0.1429$ であつた。

表28には, 有効例の中再発判定時に, 再発疑と判定さ れた症例を一覧表にして参考に供した。備考欄に*を付 したものは再発判定時の検査所見が悪化している「再発 疑例である.

表29 亿は投薬方法に関係なく，本検討の際に単独菌感 染として検出された症例の数と菌種を一覧表にした。や はりグラム陰性桿菌が多く，その中では， E. coli が圧 倒的に多いことがわかる.

表29 UTI 基準（委員会判定）単独菌検出例 (991例)

\begin{tabular}{|c|c|c|}
\hline Staphylococcus aureus & 4 & $1.0 \%$ \\
\hline Staphylococcus epidermidis & 37 & 9.5 \\
\hline$\beta$-Streptococcus Group B & 1 & 0.3 \\
\hline E. coli & 311 & 79.5 \\
\hline Citrobacter freundii & 2 & 0.5 \\
\hline Klebsiella pneumoniae & 18 & 4.6 \\
\hline Enterobacter aerogenes & 1 & 0.3 \\
\hline Proteus mirabilis & 6 & 1.5 \\
\hline Pseudomonas aeruginosa & 2 & 0.5 \\
\hline NF-GNR（未同定） & 1 & 0.3 \\
\hline Others* & 8 & 2.0 \\
\hline Total & 391 & 100.0 \\
\hline
\end{tabular}

*未同定 (dip-slide 送付中に非活性菌となつたものな ど)

表30は, 単独感染, 複数菌感染の区別なしに検出した 菌種と株数を一覧表にしたものでやはり E. coli が最多 であり，次いで Klebsiella が多い。

表31-1，31-2 は検出された菌の内，4種を選び， その MIC 分布を $10^{8} \sqsupset / \mathrm{ml}$ 及び $10^{6} \sqsupset / \mathrm{ml}$ の細菌数で測 定した表である。

\section{考按}

今回の検討は808例の 投与症例をあつめ 得たにもかか
表 30

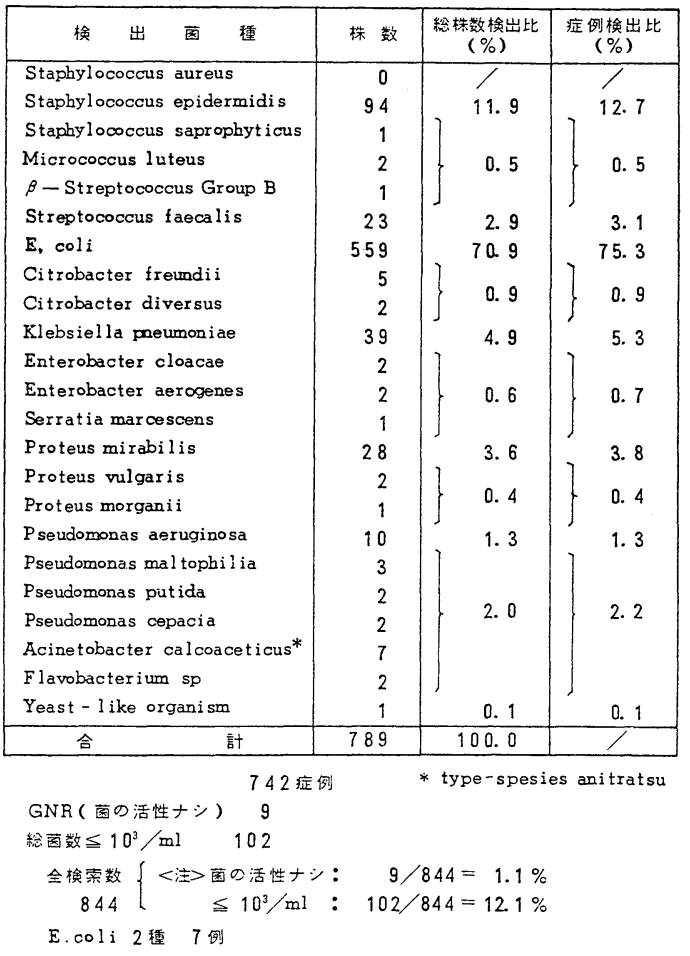

わらず，再発についての検討対象 となつたのは167例で めり，真の再発とみとめられたのは，その内 6 例といら ことになつた。特殊かつ厳密な解析を行つたため, 途中 脱落が多いのもやむを得ぬ之考光る。

女子の急性単純性膀胱炎にどの位自然治癒がめるか, またどの位自然再発があるかは，現時点では不詳であ る.しかしながら UTI 薬効判定基準を用いて判定すれ ば，その中に含まれる自然治癒の数も合算して，ある薬 剤と他の薬剤の効果を比較することができるので，今回 の trial にもこの判定基準を用いた.

尿路感染の再発に関する文献はいくつかみられるが， 14) 15) 16) 17) 18) その場合の指標は主として尿中細菌数であ

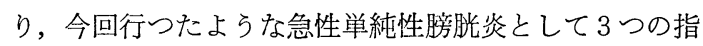
標をとな觉たものではない。

疾患として急性単純性膀脂炎をとらえるとき，UTI 薬効評価基準の患者条件に適合し，判定の対象にするも の以外の急性単純性膀脂炎もあると考兄られるが，なる べく疾患の質をそろえた上で，それに対する薬効を判定 しょうと考兄ると，ある枠をはめられた急性単純性膀胱 炎のみを扱うことになる．今回の trial で完全な再発 
表31一 1 MIC 分布 $10^{8} \mathrm{cells} / \mathrm{ml}$

\begin{tabular}{|c|c|c|c|c|c|c|c|c|c|c|c|c|c|}
\hline \multirow{2}{*}{ organism } & \multirow{2}{*}{ Drug } & \multicolumn{12}{|c|}{$\operatorname{MIC}(\mu \mathrm{g} / \mathrm{ml})$} \\
\hline & & $\leqq 0.78$ & 1.56 & 3.13 & 6.25 & 12.5 & 25 & 50 & 100 & 200 & 400 & 800 & $>800$ \\
\hline \multirow{7}{*}{559 str. } & NA & 13 & 190 & 289 & 40 & 11 & 2 & 1 & 7 & 1 & 4 & 0 & 1 \\
\hline & PPA & 96 & 406 & 42 & 6 & 7 & 1 & 1 & & & & & \\
\hline & ABPC & 2 & 22 & 363 & 37 & 4 & & 1 & 1 & 2 & 5 & 9 & 113 \\
\hline & CBPC & & 2 & 17 & 58 & 318 & 31 & 5 & 2 & 4 & 8 & 14 & 100 \\
\hline & CEX & & 2 & 8 & 44 & 408 & 85 & 6 & 2 & 2 & 1 & 1 & \\
\hline & CET & & & 4 & 25 & 269 & 245 & 6 & 1 & 1 & 4 & 2 & 2 \\
\hline & $\mathrm{GM}$ & 8 & 534 & 10 & 5 & 2 & & & & & & & \\
\hline \multirow{7}{*}{$\begin{array}{l}\text { Klebsiella pneumoniae } \\
39 \text { str. }\end{array}$} & $\mathrm{NA}$ & & 1 & 6 & 21 & 7 & 2 & & & 2 & & & \\
\hline & PPA & & 5 & 28 & 4 & 2 & & & & & & & \\
\hline & ABPC & & & & & & 1 & & & 4 & 5 & 10 & 19 \\
\hline & CBPC & & & & & & & 1 & & 2 & 4 & 10 & 22 \\
\hline & CEX & & & 2 & 18 & 12 & 5 & & 1 & & & 1 & \\
\hline & CET & & & 2 & 18 & 13 & 3 & 1 & & & 1 & & 1 \\
\hline & GM & 6 & 23 & 5 & 3 & 2 & & & & & & & \\
\hline \multirow{7}{*}{$\begin{array}{c}\text { Proteus mirabilis } \\
28 \text { str. }\end{array}$} & $\mathrm{NA}$ & & 1 & 10 & 13 & 3 & & & & & 1 & & \\
\hline & PPA & 1 & 6 & 16 & 4 & & 1 & & & & & & 2 \\
\hline & ABPC & & 4 & 19 & 2 & & & & 1 & & 1 & & 1 \\
\hline & CBPC & 1 & 8 & 14 & 1 & 1 & & 1 & & & 1 & & \\
\hline & CEX & & & 1 & 2 & 13 & 9 & 1 & 1 & & & 1 & \\
\hline & CET & & 1 & 8 & 10 & 4 & 4 & & & & & & \\
\hline & GM & 7 & 17 & 4 & & & & & & & & & \\
\hline \multirow{7}{*}{$\begin{array}{c}\text { Citrobacter spp* } \\
7 \text { str. }\end{array}$} & $\mathrm{NA}$ & & & 3 & 3 & 1 & & & & & & & \\
\hline & PPA & & 3 & 4 & & & & & & & & & \\
\hline & $\mathrm{ABPC}$ & & & & 1 & & 1 & 2 & 1 & & & & 2 \\
\hline & CBPC & & & & & 2 & 2 & 1 & & & & & 2 \\
\hline & CEX & & & & 1 & 1 & & & & 1 & 1 & & 3 \\
\hline & CET & & & & & 2 & & & & & & 2 & 3 \\
\hline & GM & 1 & 5 & 1 & & & & & & & & & \\
\hline
\end{tabular}

* Citrobacter freundii 5, Citrobacter diversus 2

は3 日分の投薬後著効々判定され，1 週後に UTI 判定 基準で言う，急性単純性膀胱炎の条件をみたすような症 状を示しているものといらかなりきびしい定義を定めた のも，これをゆるめると UTI 基準では膀胱炎として対 象にしない上うな状態が起こつても, 再発といらことに なりかねないということと，再発を起こす誘因として最 重要な因子がまだ完全にはわかつていない以上，どれも 同一の条件で，再発の誘因とならない処迄に治つたとこ ろで，再発を論じようとしたからである.1つには現在 UTI 基準により有効といら判定名で扱われている状態 は，本当はまだ疾患としては存続していて，再発につな がりやすいものであるかもしれない.それは有効の判定
をされた症例の再発を検討することによりある程度判断 されると考えられたことから，有効例の再発についての 検討も行われた. その結果は前述の如く, 著効群に比し て明らかに差があり，やはり著効と有効は別の概念で考 学るべきものであることが示唆された.

背景因子の検討で，特に目立つのは過去 1 年内に膀胱 炎に罹患した症例が約30\%といらことである，これら膀 胱炎経験群と, 非経験群の差は, 以後の統計処理でも特 に明らかになつて来てはいないが，各症例毎に別の観点 から検討を要するかもしれない。

今回の膀胱炎の起炎菌として約 $80 \%$ E. coli である というのは，他の報告に比較しても妥当なところである 
表31-2 MIC 分布 $10^{6} \mathrm{cell} / \mathrm{ml}$

\begin{tabular}{|c|c|c|c|c|c|c|c|c|c|c|c|c|c|}
\hline \multirow{2}{*}{ organism } & \multirow{2}{*}{ Drug } & \multicolumn{12}{|c|}{$\operatorname{MIC}(\mu \mathrm{g} / \mathrm{ml})$} \\
\hline & & $\leqq 0.78$ & 1.56 & 3.13 & 6.25 & 12.5 & 25 & 50 & 100 & 200 & 400 & 800 & $>800$ \\
\hline \multirow{7}{*}{$559 \mathrm{str}$} & NA & 18 & 221 & 253 & 42 & 9 & 2 & 2 & 5 & 2 & 4 & 0 & 1 \\
\hline & PPA & 98 & 406 & 43 & 6 & 5 & 1 & & & & & & \\
\hline & $\mathrm{ABPC}$ & 11 & 268 & 136 & 13 & & 2 & 2 & 7 & 12 & 17 & 20 & 71 \\
\hline & CBPC & & 2 & 22 & 86 & 311 & 11 & 3 & 4 & 10 & 13 & 15 & 82 \\
\hline & CEX & & 2 & 10 & 97 & 364 & 80 & 2 & 3 & & 1 & & \\
\hline & CET & & & 4 & 58 & 291 & 195 & 5 & 2 & 2 & & 2 & \\
\hline & GM & 23 & 527 & 7 & 2 & & & & & & & & \\
\hline \multirow{7}{*}{$\begin{array}{c}\text { Klebsiella pneumoniae } \\
39 \text { str. }\end{array}$} & NA & & 1 & 10 & 19 & 5 & 2 & & 1 & 1 & & & \\
\hline & PPA & 1 & 7 & 28 & 2 & 1 & & & & & & & \\
\hline & $\mathrm{ABPC}$ & & & & & 1 & 1 & 3 & 6 & 9 & 4 & 7 & 8 \\
\hline & CBPC & & & & & & 1 & 1 & 3 & 8 & 8 & 8 & 10 \\
\hline & CEX & & & 3 & 22 & 10 & 2 & 1 & & 1 & & & \\
\hline & CET & & & 3 & 23 & 9 & 2 & & 1 & & & 1 & \\
\hline & $\mathrm{GM}$ & 8 & 23 & 6 & 2 & & & & & & & & \\
\hline \multirow{7}{*}{$\begin{array}{c}\text { Proteus mirabilis } \\
28 \mathrm{str} .\end{array}$} & NA & & 1 & 11 & 13 & 2 & & & & 1 & & & \\
\hline & PPA & 1 & 8 & 16 & 2 & & 1 & & & & & & \\
\hline & $\mathrm{ABPC}$ & & 7 & 17 & 1 & 1 & & & & & 1 & & 1 \\
\hline & CBPC & 3 & 10 & 11 & 1 & & 1 & & & 1 & & & 1 \\
\hline & CEX & & & 1 & 5 & 13 & 7 & 1 & & 1 & & & \\
\hline & CET & & 1 & 9 & 11 & 4 & 2 & & & 1 & & & \\
\hline & GM & 11 & 15 & 2 & & & & & & & & & \\
\hline \multirow{7}{*}{$\begin{array}{c}\text { Citrobacter spp* } \\
7 \text { str. }\end{array}$} & NA & & 2 & 4 & & 1 & & & & & & & \\
\hline & PPA & & 5 & 2 & & & & & & & & & \\
\hline & ABPC & & & 1 & & 1 & 3 & & & & & 1 & 1 \\
\hline & CBPC & & & & 1 & 3 & 1 & & & & 1 & & 1 \\
\hline & CEX & & & & 1 & 1 & & 1 & & 1 & & 1 & 2 \\
\hline & CET & & & & & 2 & & & & 1 & 1 & & 3 \\
\hline & $\mathrm{GM}$ & 2 & 5 & & & & & & & & & & \\
\hline
\end{tabular}

* C. freundii 5, C. diversus 2

表32 NA 発売（1964年12月）時点の臨床成績 一主要な論文から一

\begin{tabular}{|c|c|c|c|c|c|c|c|c|c|c|c|}
\hline \multirow{2}{*}{$\begin{array}{l}\text { 雑誌發表 } \\
\text { 表 }\end{array}$} & \multirow{2}{*}{ 対象疾患 } & \multirow{2}{*}{ 例数 } & \multirow{2}{*}{ 臭賞症状 } & \multirow{2}{*}{ 袐临䋰 } & \multicolumn{2}{|c|}{ 尿中細菌陰性化 } & \multirow{2}{*}{ 著 効 } & \multirow{2}{*}{ 有 効 } & \multirow{2}{*}{ 無 効 } & \multirow{2}{*}{1 日用量 } & \multirow{2}{*}{ 抯㭔 } \\
\hline & & & & & 検 鏡 & 培 養 & & & & & \\
\hline 大 $_{1964}^{\text {越他 }}$ & $\begin{array}{l}\text { 外来患者 } \\
\text { 膀腅炎 }\end{array}$ & 37例 & $\begin{array}{c}32 \\
(89 \%)\end{array}$ & $\begin{array}{c}28 \\
(78 \%)\end{array}$ & $\left(\begin{array}{c}30 \\
(83 \%)\end{array}\right.$ & ( $78 \%)$ & 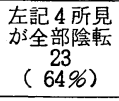 & 記載なし & 記載なし & $\begin{array}{c}2 \mathrm{~g} \text { 中心 } \\
(4 \mathrm{~g} \text { もあり })\end{array}$ & 1 12日 \\
\hline 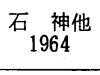 & 急性䧛胼炎 & 6例 & $(100 \%)$ & 記載なし & & ${ }^{* 1}(100 \%)$ & $\begin{array}{c}6 \\
(100 \%)\end{array}$ & 0 & 0 & $\begin{aligned} 4 \mathrm{~g} \\
\text { (分 } 4 \text { ) }\end{aligned}$ & $\begin{array}{c}3 \widetilde{7} \text { 和 } \\
4.2 \text { 日均 }\end{array}$ \\
\hline $\begin{array}{l}\text { 西 }{ }_{1964} \text { 浦他 } \\
\end{array}$ & 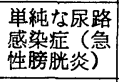 & 7例 $* 2$ & $(100 \%)$ & $(100 \%)$ & & $(100 \%)$ & $(100 \%)$ & 0 & 0 & $\begin{array}{r}4 \mathrm{~g} \\
\text { (3) } 4 \text { ) }\end{array}$ & $\begin{array}{c}3 \sim 100 \\
\text { 平堨 } \\
7 \text { 日量 }\end{array}$ \\
\hline \multirow[t]{2}{*}{$\begin{array}{c}\text { 江_本他 } \\
\begin{array}{c}\text { (百頼) } \\
1966\end{array} \\
\end{array}$} & 急性営路感煠怢 & 17例 & $\begin{array}{l}14 \\
(82 \%)\end{array}$ & $\left(\begin{array}{c}15 \\
(88 \%)\end{array}\right.$ & $(13$ & $\begin{array}{l}13) * 3 \\
(100 \%)\end{array}$ & $\begin{array}{c}14 \\
(82 \%)\end{array}$ & 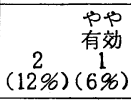 & 0 & $1.5 \mathrm{~g}$ & $\begin{array}{l}\text { 平均 } \\
5.3 \text { 日 }\end{array}$ \\
\hline & & 67例 & $\begin{array}{c}59 / 67 \\
(88 \%)\end{array}$ & $\begin{array}{l}50 / 61 \\
(82 \%)\end{array}$ & & $63(86 \%)$ & $\begin{array}{c}50 / 67 \\
(75 \%)\end{array}$ & & & & \\
\hline
\end{tabular}

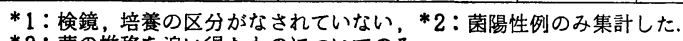

*3: 菌の推移を追い得たものについてのみ. 
らと思われるが8 ${ }^{13)}$ ，複数菌感染例の 比率はやや高い と感じられる。

NA 2g 3 日間投与の 効果は，有効率 $85.6 \%$ である. この薬剤がはじめて本邦に紹介された頃には，今日のよ らに尿路感染症の薬効判定を統一し上らとする動きも明 らかではなく，判定方法もまちまちであるが，表32の如 く，もら少し効果が良かつたという印象を与兄る ${ }^{4) \sim 7}$. 十数年間に類似の化学構造を有する薬風の増加もあり, 耐性菌の増加をきたした結果と考えている．菌種別には E. coli には90\%以上に NA が有効, S. epidermidis に は50\%以下の有効率で，本剤の桿菌に強いという特性を あらわしている。

主治医による有用性判定では，一般の trial と異なり UTI 基準による判定よりもきびしく判定された傾向が あり， $78.2 \%$ の有効率であつた。

薬剤の効果は, 再発の有無をも加えて判定されるべき いう考え方をすれば，今回の trial は，その面からで も有効群と著効群は別のものであることを示したとい兄 る.

再発を判定する時に問題となる点が数点ある.

第 1 はUTI 判定基準は薬効を判定するもので, 治癒 を判定しているのではないという点である. 即ち 3 日分 投与後に有効と判定された症例が，その後治瘾するか否 かについての検討はなされていない，再発を論ずるな ら，一旦疾患の治癒を確認してから論ずるべきだとする 考え方もあろ ${ }^{14) 15)}$. 今回著効例のみを主体として論じ たのは，著効と判定される例は治癒しているとみなして よい症例であろらといら含みもあるが，7日間治療群の ほうが 3 日間治療群より, 再発敊よび再発疑が少ないと いら成績（表25）は，3 日間治療群の著効例のなかには まだ細菌が残在していた症例も含まれていたといら可能 性もありらると考点られる。

第 2 に再発の検討を 1 週間後としているが，これが期 間的に妥当なものか否かは, 経験的に follow up 可能 な期間はこの位と考劣ただけで，何等の根拠もない。 た途中の経過を経時的に検討した例もなく，はたして7 日目が適当か否かは結論でさぬ, 特に 7 日目以後の経過 については，たと无発しても集計して扣らず，何も論 ずることがでさない。

第 3 亿急性単純性膀脱炎の原因菌については, 複数菌 感染でも単独感染でも，すべて総菌数のみを問題にして 抢り, 薬効判定時及び再発判定時にも注ぼ同様である. 初めの感染菌と同一菌が再発したのか, 同一菌でも型の
違うすのか等については条件をつけていない，再発の中 飞再然と再感染を含めて扱つたのでこの点も将来問題と なるかもしれない。

急性単純性膀脱炎の再発については, 本邦では河田の 報告 ${ }^{16)}$ がみられる.その方法は本論文の方法とはやや異 なり，3 日間の薬剤投与に続いて 1 週間目に再発検討を 行つているが再発の定義は尿中生菌数 $10^{4} \mathrm{~J} / \mathrm{ml}$ 以上又 は膿尿の増悪である.さらにそれらの症例の一部につい ては 2 年にも及ぶ再発の監視を行つているが，再発率は 1 週間内のものが約 $15 \%$ であり，年㱓の高い程再発も多 く，そのらち2/3は再感染であると結論されている. 本 論文と再発の定義が異なるので同列には論ぜられない が, 効果判定時, 有効とされ, 菌が尿中になかつたが再 発した症例は表 24 にとめられる如く 2 例であり, 有効 と判定され尿中細菌 0 であり, 後に $10^{4} ב / \mathrm{ml}$ 以上とな つたが，他の条件がそろわず再発と判定されなかつた例 は，表28の中からよみとれる如く 1 例もなかつた. 追跡 期間を投薬中止後 1 週間と限定しているので, 河田論文 の如く再発に関する年龄差, 膀胱炎の既往による差等は 長期追求できていない。

以上を要約して次の如く結論できる。

1. 急性単純性膀胱炎を NA 1 日 $2 \mathrm{~g}$ 投与で治療する 場合, 3 日間投与より 7 日間投与の方が再発が少ない。

2. NA 2g 3 日間投与で，著効及び有効例の 7 日間 追跡調査では，その間 NA $1 \mathrm{~g}$ 就寝前投与を行つた汪ら が，少量の抗炎症剤を与えたもの，および何も与充なか つたものより再発率が低かつた。（但しこの1日1g と いら量は，再発防止量としてはやや多かつたのではない かとも考兄られる）

3. 3 日目薬効評価の時点で, 尿中細菌が残存してい る症例のほうが再発率が高いといら結果が出たが，これ は当然のこととい兄るであろう。これに関連あること で, 著効例群と有効例群の再発率をみると, 前者の方が 有意に低かつた。

終りに本研究の菌検索の部門において絶大な御協力を 頂いた東京総合臨床検査センター出口浩一氏に深甚の謝 意を表する次第である。

\section{文献}

1) 大越正秋, 河村信夫 : 尿路感染症における薬効 評価基準. Chemotherapy, 28, 321-341，1980; 臨泌, 34, 85-91, 1980.

2) 河田幸道, 西浦常雄 : 尿路感染症に打ける化学 療法剤の薬効評価法について。第 1 報, 単純性 尿路感染症に打汀薬効評価基準, 日泌尿会 
誌, 70， 317-326， 1979.

3) 河村信夫 : UTI 薬効評価基準（第 2 版）の紹介 と解説。腎と透析，8，25-32，1980.

4) 西浦常雄, 横山繁, 石神行雄 : 新化学療法剤 Nalidixic acid の治験. 泌尿紀要，10，41-46， 1964.

5) 大越正秋, 生亀芳雄, 高村正衛, 藤村 伸 : Nalidixic acid (ウイントマイロン) による尿路 感染症の治療。治療, 46, 953-958, 1964.

6) 石神襄次, 原 信二, 吉田 泰: 新化学療法剤 WIN-18320の尿路感染症における応用. 臨皮 泌, 18, 1099-1102, 1964.

7) 江本㑆一, 熊沢浄一, 梄橋勝利, 原孝彦: Nalidixic acid（ウイントマイロン）による尿路 感染症の 治療成績。 chemotherapy, 14，226一 228, 1966.

8）百瀬俊郎, 熊沢浄一, 坂本公孝, 大島一寛, 江 藤耕作, 境 優一, 池上奎一, 野村芳雄, 近藤 厚, 斉藤 泰, 石沢靖之, 妹尾康平, 岡元健一 郎, 大井好忠, 大沢 昫: 複雑性尿路感染症に 対する Cinoxacin の臨床効果一Nalidixic acid との二重盲検比較試験一. chemotherapy 28 (S4) $377-398,1980$.

9）熊沢浄一, 百瀬俊郎, 平田耕造, 日高正昭, 太 田康弘, 上田豊史, 原 三信, 原 孝彦, 後藤 宏一郎, 南里和成, 石津芳和, 有吉朝美, 楢橋 勝利, 横山譲二, 永芳弘之, 中山宏, 岩坪映 二, 玉丸鴻一, 清原宏彦, 相戸賢二, 藤沢保仁, 平田弘, 長田幸夫, 小川暢也, 中野重行 : 急 性単純性膀胱炎に対する Piromidic acid の効 果一二重盲検比較試験一. chemotherapy. 19, $657-664,1971$.

10）玲木恵三, 木村茂三，橋本達也，土方允久, 名 出頼男：新抗菌性薬剤 Piromidic acid (PA) の 急性単純性膀胱炎に対する臨床効果一Nalidixic acid (NA) との二重盲検法による比較検討一. chemotherapy. 19, 582-595，1971.

11) 石神襄次, 三田俊彦, 片岡頌雄, 宮崎 重, 金 田州弘，大西真尚，古川玄教，黒田守，広岡 九兵衛, 末光 浩, 富岡 収, 寺杣一德, 大野
三太郎, 林 法信, 原 信二, 斉藤 博, 伊藤 登, 黒田清輝, 日根野卓, 田中邦彦, 上原口弘, 森脇 宏, 彦坂幸治, 安室朝三 : 二重盲検法に よるPipemidic acid と, Piromidic acid の急 性下部尿路感染症に対する比較臨床試験. Jap. J. antibiot. 29, 167-177, 1976.

12）石神襄次, 原 信二, 阿岸鉄三, 斉藤 博, 長 浜通正, 守殿貞夫, 三田俊彦, 田中邦彦, 寺杣 一德, 片岡頌雄, 末光 浩, 大野三太郎, 玉置 明, 柴 務, 清岡政德, 黒田清輝, 黒田守, 広岡九兵衛 : Piromidic acid の二重盲検法によ る急性膀胱炎に対する臨床評価. chemotherapy 19, 631-644, 1971 .

13) 大井好忠, 岡元健一郎, 川香尚志, 小香道夫, 永田進一, 永田耕一, 片平可也, 冨山哲郎, 阿 世知節夫, 坂本日朗, 新福隆, 陣内謙一, 前山 泰典, 角田和之, 長沼弘三郎, 後藤俊弘, 石橋 丸応，小川啺也：急性単純性膀胱炎に対する AB-206 と Nalidixic acid の二重盲検法による 臨床有用性の比較. 西日泌尿, 41, 445-456, 1979.

14）村上信乃，藤田道夫，田村欣一，大谷かおる， 長谷川範子, 三橋慎一：女子反覆性膀胱炎につ いて一第 1 報: 外用薬剤の効果一. 臨泌, 31, $413-417,1977$.

15) 村上信乃, 藤田道夫, 香村衡一：女子反覆性膀 胱炎について一第 3 報: 長期化学療法の効果一。 臨泌, 34, 861-865, 1980.

16) 河田幸道, 西浦常雄, 田原達雄 : 尿路感染症の 再発に関する臨床的研究。日泌尿会誌，71， $132-142,1980$.

17) Turck, M.: Optimal duration of treatment of chronic urinary tract infections. Ann. Int. Med., 69, 837-839, 1968.

18) Prat, V., Bohuslav, V. and Hatada, M.: Daily bacteriological examination of urine during antimicrobial treatment of urinary tract infections. Int. Urol. Nephrol., 11, 3-10, 1979. （1981年 5 月 29 日受付, 特別掲載） 